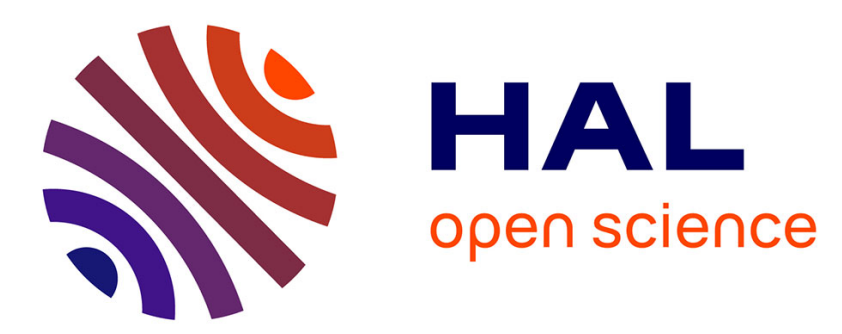

\title{
Thermochronological Evidence of Early Orogenesis, Eastern Pyrenees, France
}

Sébastien Ternois, Margaret Odlum, Mary Ford, Raphael Pik, Daniel Stockli, Bouchaib Tibari, Arnaud Vacherat, Vincent Bernard

\section{To cite this version:}

Sébastien Ternois, Margaret Odlum, Mary Ford, Raphael Pik, Daniel Stockli, et al.. Thermochronological Evidence of Early Orogenesis, Eastern Pyrenees, France. Tectonics, 2019, 38 (4), pp.1308-1336. 10.1029/2018TC005254 . hal-02394226

\section{HAL Id: hal-02394226 \\ https://hal.univ-lorraine.fr/hal-02394226}

Submitted on 13 Aug 2021

HAL is a multi-disciplinary open access archive for the deposit and dissemination of scientific research documents, whether they are published or not. The documents may come from teaching and research institutions in France or abroad, or from public or private research centers.
L'archive ouverte pluridisciplinaire HAL, est destinée au dépôt et à la diffusion de documents scientifiques de niveau recherche, publiés ou non, émanant des établissements d'enseignement et de recherche français ou étrangers, des laboratoires publics ou privés.

$$
\text { Copyright }
$$




\section{Tectonics}

\section{RESEARCH ARTICLE \\ 10.1029/2018TC005254 \\ Key Points: \\ - Zircon (U-Th)/He data record a cooling phase during early convergence in the Pyrenean low-relief retrowedge (Agly-Salvezines block) \\ - Forward and inverse thermal history modeling reveals limitations in current radiation damage-annealing models for He diffusion in zircon \\ - Crustal section sequential restoration demonstrates that tectonic processes alone can generate rapid cooling during early orogenesis}

Supporting Information:

- Supporting Information S1

- Data Set S1

Correspondence to:

$\mathrm{S}$. Ternois,

seb.ter@hotmail.fr

Citation:

Ternois, S., Odlum, M., Ford, M., Pik, R., Stockli, D., Tibari, B., et al. (2019). Thermochronological evidence of early orogenesis, eastern Pyrenees, France. Tectonics, 38, 1308-1336. https://doi. org/10.1029/2018TC005254

Received 26 JUL 2018 Accepted 24 JAN 2019 Accepted article online 2 FEB 2019 Published online 10 APR 2019

(C)2019. American Geophysical Union. All Rights Reserved.

\section{Thermochronological Evidence of Early Orogenesis, Eastern Pyrenees, France}

\author{
Sébastien Ternois ${ }^{1}$ (D) Margaret Odlum ${ }^{2}$ (D), Mary Ford ${ }^{1}$ (D), Raphaël Pik ${ }^{1}$ (D), Daniel Stockli² ${ }^{(D}$, \\ Bouchaïb Tibari $^{1}$, Arnaud Vacherat ${ }^{1}$ iD, and Vincent Bernard ${ }^{1}$ \\ ${ }^{1}$ Centre de Recherches Pétrographiques et Géochimiques, UMR 7358 CNRS-Université de Lorraine, Vandoeuvre-lès- \\ Nancy, France, ${ }^{2}$ Department of Geological Sciences, Jackson School of Geosciences, University of Texas, Austin, TX, USA
}

\begin{abstract}
In collisional orogens, distinguishing the thermal signature of early orogenesis from the preceding rift or from subsequent thermal events is a major challenge. We present an integrated geological and low-temperature thermochronology study of the Paleozoic Agly-Salvezines crustal block in the retrowedge of the eastern Pyrenees (France). The northern Pyrenees preserves one of the best geological records of a rift-to-collision transition. The Agly-Salvezines block represents the inverted distal European margin of an Aptian-Cenomanian rift system. Seventeen samples were collected throughout the external orogenic massif and analyzed for low-temperature thermochronology: zircon (U-Th)/He dating documents the cooling history of the massif during the initiation and early phase of Pyrenean convergence, while apatite (U-Th)/He dating completes the record of plate collision. Using inverse and forward modeling of new low-temperature thermochronology data, we show that the Pyrenean retrowedge records two clear phases of orogenic cooling, Late Campanian-Maastrichtian and Ypresian-Bartonian, which we relate to early inversion of the distal rifted margin and main collision, respectively. An earlier, late Aptian-Turonian cooling history is detected, possibly related to rifting and/or postrift. No cooling is evidenced during the Paleocene during which tectonic quiescence is recorded in the adjacent Aquitaine retroforeland basin. Using our low-temperature thermochronology data and geological constraints, we propose a crustal-scale sequentially restored model for the tectonic and thermal transition from extension to peak orogenesis in the eastern Pyrenees, which suggests that both thrusting and underplating processes contributed to early inversion of the Aptian-Cenomanian rift system.
\end{abstract}

\section{Introduction}

The Pyrenean orogen was generated from late Santonian-early Campanian to middle Miocene by N-S convergence of the Iberian and European plates (Choukroune, 1989; Muñoz, 1992; Macchiavelli et al., 2017). External orogenic zones and foreland basins record two distinct periods of low but accelerating tectonic shortening and subsidence, latest Santonian-Danian and Thanetian-Oligocene, separated by a quiet (very low to near-zero subsidence) period during the Paleocene (Ford et al., 2016). These two periods are recognized to be synorogenic and mark two phases of convergence, the second generally recorded as Eocene-Oligocene in low-temperature thermochronology studies. Significantly, the orogen's three-phase convergence history does not correspond to behavior predicted by foreland dynamic models (Naylor \& Sinclair, 2008; Sinclair et al., 2005; Sinclair \& Naylor, 2012). While the evolution of crustal thickening, thermicity, orogen relief, and erosion during the main Eocene-Oligocene collisional phase are well studied and show a clear link to foreland basin dynamics (Fillon et al., 2013; Sinclair, 2011), the early Pyrenean history of convergence and the subsequent phase of quiescence are poorly constrained. In particular, there are few data on the thermal and dynamic behavior of the orogen during the earliest phase of Pyrenean convergence. The record of early orogenesis is best observed in the retrowedge where shortening and translation values are low (Naylor \& Sinclair, 2008) and where the main Aptian-Cenomanian rifting phase is preserved. In this paper we present new zircon and apatite (U-Th-Sm)/He (ZHe and AHe, respectively) data from an external Paleozoic crustal block, Agly-Salvezines (Figures 1 and 2), in the eastern Pyrenean retrowedge. By integrating these data with new and published geological data, we address the following questions: Can we recognize a thermal signature for the onset of Pyrenean convergence and for Paleocene quiescence? Are early crustal thermal events contemporaneous with early foreland tectonic events, or is there a lag time between these two phenomena? Can we distinguish an early orogenic thermal signature from other thermal events such as those associated with preceding rifting or later collision? 


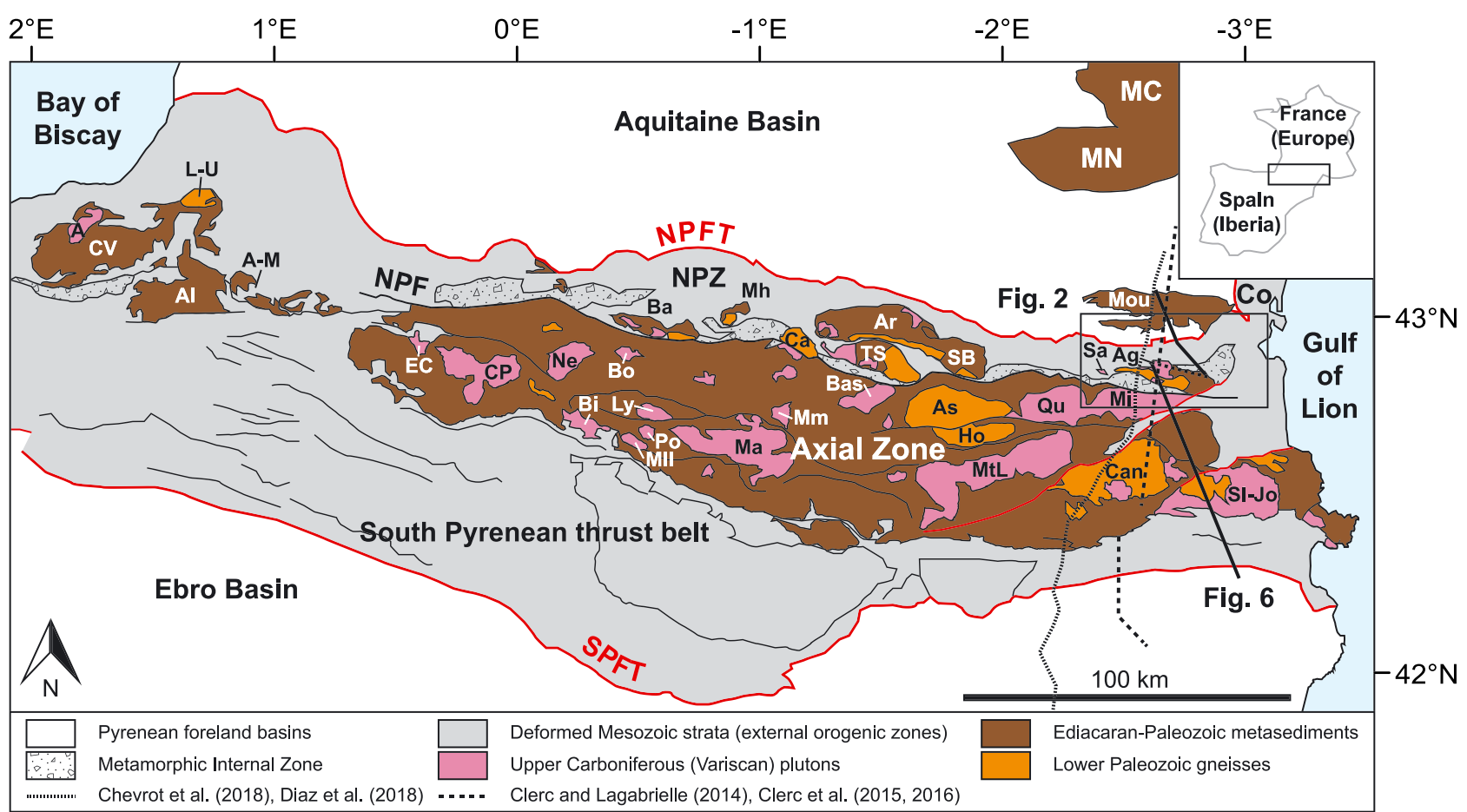

Figure 1. Simplified tectonic map of the Pyrenees showing the main tectonic units, the location of the study area (Figure 2), the position of the crustal-scale crosssectional model proposed in this paper (Figure 6), and the location of (i) the North Pyrenean basement massifs and (ii) the main plutons/gneiss domes in the Axial Zone. NPFT $=$ North Pyrenean Frontal Thrust; NPZ = North Pyrenean Zone; NPF = North Pyrenean Fault; SPFT = South Pyrenean Fault; MN $=$ Montagne Noire; $\mathrm{MC}=$ Massif Central; $\mathrm{Mou}=$ Mouthoumet; $\mathrm{Co}=$ Corbières. (i) L-U = Labourd-Ursuya; $\mathrm{CV}=$ Cinco Villas; $\mathrm{Al}=\mathrm{Aldudes;} \mathrm{A}-\mathrm{M}=\mathrm{Arbailles}-\mathrm{Mendibelza}$; $\mathrm{Ba}=$ Barousse $; \mathrm{Mh}=$ Milhas; $\mathrm{Ca}=$ Castillon; $\mathrm{Ar}=$ Arize; $\mathrm{TS}=$ Trois Seigneurs; $\mathrm{SB}=$ Saint-Barthélémy; Ag = Agly; Sa = Salvezines. (ii) A = Aya; EC = Eaux Chaudes; $\mathrm{CP}=$ Cauterets-Panticosa; $\mathrm{Ne}=$ Néouvielle; $\mathrm{Bi}=$ Bielsa; $\mathrm{Bo}=$ Bordères; Mil = Millares; Po = Posets; Ly $=$ Lys-Caillaouas; Ma $=$ Maladeta;

$\mathrm{Mm}=$ Marimanha; Bas = Bassiès; As = Aston; Ho = Hospitalet; MtL = Mont-Louis; Qu = Quérigut; Mi = Millas; Can = Canigou-Carança; Sl-Jo = Saint Laurent-La Jonquera.

The Pyrenean case study has both advantages and challenges for the study of early orogenesis. Advantages include a low total convergence (92-165 km; Beaumont et al., 2000; Mouthereau et al., 2014; Muñoz, 1992; Roure et al., 1989; Teixell et al., 2018, 2016) allowing better preservation of early phases than in highconvergence orogens. There is also no thermal signature of subduction preceding collision, as is the case in many orogens, because no true oceanic crust was formed before the onset of convergence (Clerc \& Lagabrielle, 2014; Jammes et al., 2009; Lagabrielle et al., 2010; Lagabrielle \& Bodinier, 2008; Masini et al., 2014; Tugend et al., 2014). On the other hand, the Aptian-Cenomanian rifting generated a major thermal pulse that had not reequilibrated before the onset of convergence some 10 myrs later (Angrand et al., 2018). This inherited thermal perturbation may have been present during the first 30-35 myrs of orogenesis (Angrand et al., 2018; Vacherat et al., 2014), maintaining temperatures during early orogenesis above the sensitivity limit of low-temperature thermochronometers (40-300 ${ }^{\circ} \mathrm{C}$; e.g., Carrapa, 2010; Peyton \& Carrapa, 2013) and thus delaying any cooling record until the main Eocene collision (Vacherat et al., 2016). However, previous limited low-temperature thermochronology data (Yelland, 1991) indicate that the massifs at the eastern end of the external Pyrenean orogenic system, Agly-Salvezines, record a CampanianMaastrichtian cooling signal, synchronous with the first period of accelerating subsidence in the retroforeland (Ford et al., 2016). This signature is absent in more proximal crystalline massifs further west, which only record Eocene exhumation (e.g., Vacherat et al., 2016), with the exception of the Labourd-Ursuya Massif at the extreme western end of the orogen (Figure 1; Yelland, 1991; Vacherat et al., 2014). As paleotemperature data obtained by Raman spectroscopy on carbonaceous material (RSCM; Clerc et al., 2015; Chelalou et al., 2016, and references therein) and radiometric data (Clerc et al., 2015, and references therein) for Mesozoic sediments suggest higher postrift cooling rates from end of rifting to the onset of convergence in the eastern Pyrenean retrowedge, we can expect paleotemperatures at the onset of orogenesis to be lower in this region. A 


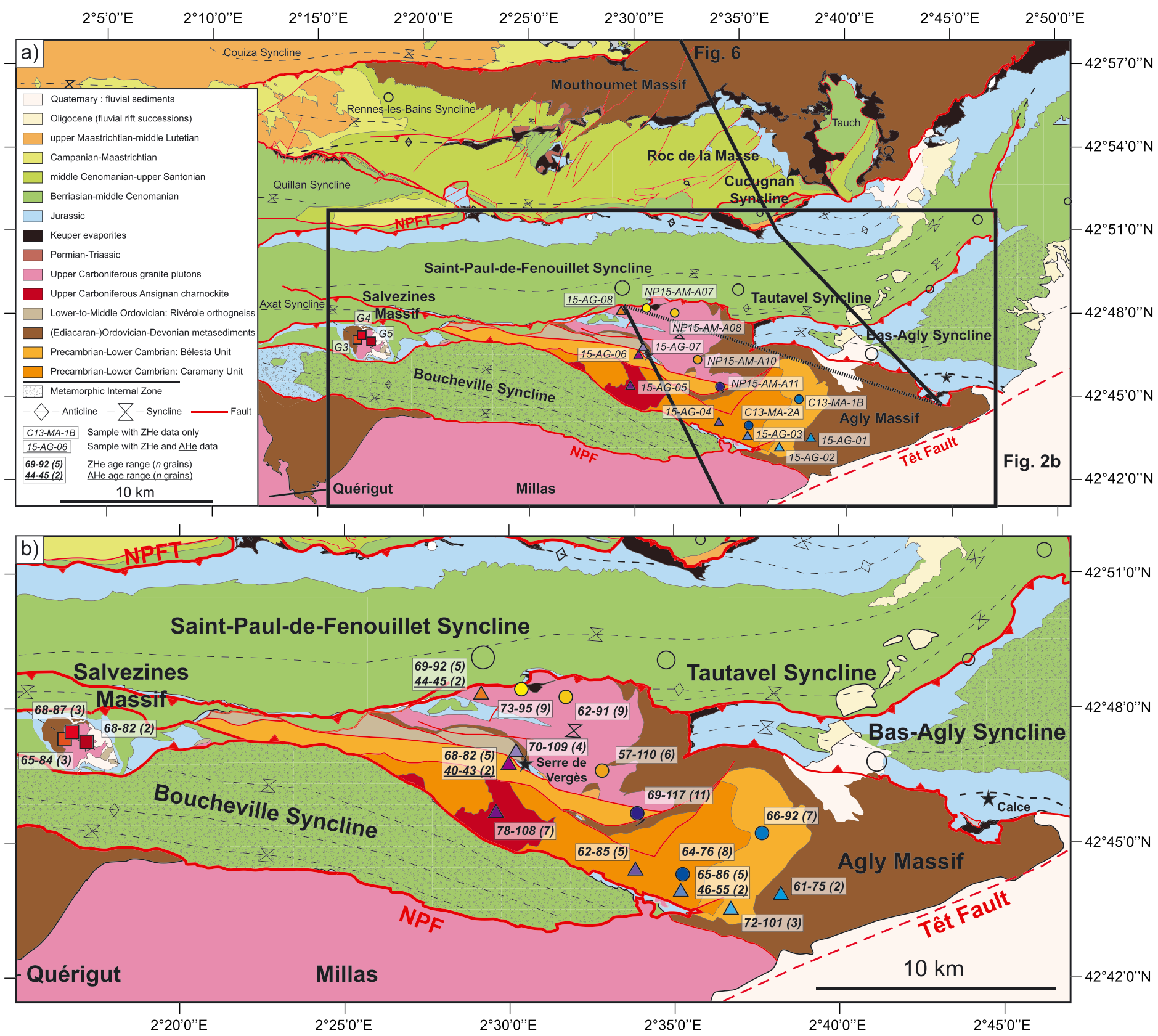

Figure 2. Geological map of the Agly-Salvezines area, based on maps published by the BRGM (Bureau de Recherches Géologiques et Minières; Quillan: Bessière et al., 1989; Crochet et al., 1989; Tuchan: Berger, Alabouvette, et al., 1997; Berger, Bessière, et al., 1997; Rivesaltes: Berger et al., 1993; Fonteilles et al., 1993), showing the main structural elements and lithologies. The position of the crustal-scale sequentially restored cross-sectional model proposed in this paper (Figure 6) is indicated. Samples analyzed in this study are grouped into igneous/northern compartment rocks (yellow-red symbol colors) and metamorphic/southern compartment rocks (purple-blue symbol colors). Corresponding model results are shown in Figures 4, 5, S3, S5, and S6. Sample names underlined have been dated by both $\mathrm{ZHe}$ and AHe methods.

clear low-temperature thermochronology signal of the onset and early phase of orogenesis is therefore most likely to be preserved in the east, specifically in the Agly-Salvezines block.

Campanian-to-Maastrichtian successions of the early Pyrenean foreland basins record sediment supply from a main eastern source area (Bilotte, 1985; Monod, 2014; Plaziat, 1981), which has since been destroyed by the Oligocene-Miocene opening of the Gulf of Lion (Séranne, 1999; Gunnell et al., 2008, 2009). The early orogenic wedge supplied little or no sediment at this time and therefore was of low relief, probably largely submarine (Ford et al., 2016). During the Eocene main collision, the growth of major orogen relief then 
migrated from east to west (Whitchurch et al., 2011, and references therein). Mass balance models predict that orogen relief will grow as long as topographic uplift (due to crustal thickening) is not balanced by erosion (growth phase; Willett et al., 1993; Willett \& Brandon, 2002). Once this balance is achieved, the orogen passes to a steady state phase. Numerical models that use thermochronology data to constrain the thermal evolution of a growing orogen (e.g., Batt et al., 2001; Batt \& Braun, 1997, 1999) have always evoked uplift and erosion to interpret cooling events. However, in the case of early orogenic wedge growth, erosion is expected to be nonsignificant. This could result in a negligible perturbation in thermal gradients at closure temperature depths, therefore questioning the potential of low-temperature thermochronology to record cooling related to the onset of orogenesis. However, as the recent work of Mesalles et al. (2014) has highlighted, crustal thickening by early underthrusting alone may lower the geotherm of distal rifted margins due to the downward deflection of isotherms. This implies that low-temperature thermochronology data may indeed record the initial stage of convergence.

In this paper we present a detailed low-temperature thermochronology record of early convergence in the eastern Pyrenees, more precisely in the Agly-Salvezines region where the inverted distal margin of the Aptian-Cenomanian hyperextended rift system is preserved. We show that the easternmost massifs of the northern Pyrenees, unlike their more westerly counterparts, record two distinct cooling events during convergence, Campanian-Maastrichtian (ZHe data) and Ypresian-Bartonian (AHe data), separated by a period of very little cooling in the Paleocene. We argue that the early convergence cooling was due to early orogenic wedge thickening by underplating of the Iberian distal margin beneath the Agly-Salvezines crustal block and coeval northward thrusting of this block onto the colder, northern European crust. Exhumation of the thickening crust (wedge thickening by basal accretion coupled with erosion) is evoked as the principal cooling mechanism for the Eocene main convergence cooling event. Erosion-related exhumation then progressively migrated south. We discuss the implications of these new results for models of orogenic growth in the Pyrenees and for early convergence in general.

\section{Geological Setting}

The Pyrenean mountain belt is a relatively narrow (100-km-wide), double-wedged orogenic system trending $\mathrm{N} 110^{\circ}$ and extending over $1,500 \mathrm{~km}$ from the Cantabrian platform in northern Spain to the Mediterranean Sea (Languedoc-Provence) in southwestern France (Figure 1). The orogen is divided into five tectonostratigraphic zones. The external orogenic zone on the southern Iberian plate comprises the South Pyrenean fold and thrust belt and the Ebro (foreland) Basin (Vergés et al., 1995, 1998). The South Pyrenean Frontal Thrust (SPFT) separates the two systems. The Axial Zone in the core of the Pyrenean range consists of south-verging thrust sheets of Variscan metasediments and basement (Barnolas et al., 1996; Muñoz, 1992, and references therein). The Aquitaine (foreland) Basin and the North Pyrenean Zone form the retroforeland system on the northern European plate separated by the North Pyrenean Frontal Thrust (NPFT; Biteau et al., 2006; Souquet et al., 1977).

The Pyrenean chain was built on a complex crustal template. Basement blocks of the North Pyrenean Zone, namely, the North Pyrenean basement massifs (Choukroune, 1974), and the Axial Zone consist of Ediacaran-Paleozoic metasedimentary and Ordovician-to-Early Permian plutonic rocks recording the Variscan orogeny (e.g., Barnolas et al., 1996, and references therein). This orogeny was followed by two phases of Mesozoic extension or transtension, the first occurring from Triassic to Late Jurassic in an east-west zone linking the Tethys and Central Atlantic oceans (e.g., Curnelle et al., 1980). Rifting from late Aptian to early-to-middle Cenomanian (114-97 Ma) then created deep marine depocenters (Debroas, 1987, 1990), adjacent to the North Pyrenean basement massifs and associated with exhumation of mantle rocks (Azambre \& Ravier, 1978; Clerc et al., 2012; Lagabrielle et al., 2010; Lagabrielle \& Bodinier, 2008).

\section{Thermal History of the Pyrenean Orogeny}

\subsection{Pyrenean Thermal History}

Extensive low-temperature thermochronology studies in the Pyrenees over the last 20 years have produced a world-class data set to constrain crustal thermal behavior during orogenesis (Bosch et al., 2016; Hart et al., 2017; Labaume et al., 2016; Mouthereau et al., 2014, and references therein; Rushlow et al., 2013; 
Thomson et al., 2017; Vacherat et al., 2014, 2016). Bedrock low-temperature thermochronology (AHe and apatite fission track [AFT]) data from the Axial Zone and the basement massifs in the central North Pyrenean Zone record only the Eocene-Oligocene (50-20 Ma) main collision cooling history, younging from east to west and from north to south (Mouthereau et al., 2014; Whitchurch et al., 2011).

In contrast, relatively little is known about the thermal history of the early phase of Pyrenean convergence (latest Santonian to Danian). Sparse detrital AFT, ZHe and zircon fission track (ZFT) data from early, synorogenic depocenters (southern Pyrenees: Filleaudeau et al., 2012; Fillon et al., 2013; Whitchurch et al., 2011) indicate that significant relief already supplied southern depocenters. However, foreland basin sedimentary records show that up to the Eocene, this relief lay to the east of the present-day mountain range (Bilotte, 1985; Monod, 2014; Plaziat, 1981). This suggests that an active orogenic zone existed further east for which two early cooling events are probably recorded by limited detrital low-temperature thermochronology data (95-135 and 60-80 Ma; Filleaudeau et al., 2012; Whitchurch et al., 2011; 85-110 and 60-85 Ma; Mouthereau et al., 2014; Vacherat et al., 2017). The early Pyrenean orogen itself (Central Pyrenees) probably formed a low relief or even submarine edifice (Ford et al., 2016; Vacherat et al., 2017), with slow exhumation $(0.2 \mathrm{~km} / \mathrm{Myr})$ and little sediment yield until the late Eocene (Fillon \& van der Beek, 2012; Fitzgerald et al., 1999). We would therefore expect that any sediments sourced from this area would be restricted to the upper, thermally non-reset levels of the crust.

Nevertheless, an early (Campanian to Maastrichtian) cooling event is recorded in sparse bedrock ZFT and ZHe data from Variscan basement massifs of the western (Labourd-Ursuya; Vacherat et al., 2014; Yelland, 1991) and eastern (Agly; Yelland, 1991) North Pyrenean Zone. Several factors may contribute to the lack of a clear record of early orogenic cooling. It is possible that sampling has been, as yet, too sparse to detect this early event. However, early crustal thickening probably affected only the distal rifted margin, migrating outward to the proximal areas with time (definition of "distal" and "proximal" according to Sutra et al., 2013). Another reason could be simply that the early record of convergence in the Central Pyrenees was eroded away off the Axial Zone sometime from the Late Cretaceous to present (e.g., Filleaudeau et al., 2012; Rushlow et al., 2013; Thomson et al., 2017; Whitchurch et al., 2011). Only the more distal areas would have preserved the record of early orogeny. In any case, basement of the distal margin is poorly preserved in the orogen. Basement massifs in the eastern North Pyrenean Zone are, however, recognized as representing the distal upper plate (Agly and Salvezines; e.g., Clerc \& Lagabrielle, 2014; Clerc et al., 2016).

\subsection{The North Pyrenean Zone}

The North Pyrenean Zone is a 10- to 40-km-wide, north-verging thrust system (Figure 1). This zone lies between the NPFT to the north and the steeply dipping North Pyrenean Fault (NPF) to the south that is generally accepted as the surface trace of the plate boundary (Choukroune, 1989). It consists of a deformed Triassic to Turonian sedimentary succession, overlying Variscan basement that is exposed in the North Pyrenean basement massifs (Baby et al., 1988; Barnolas et al., 1996; Choukroune, 1974, and references therein).

The eastern North Pyrenean basement massifs show widespread hydrothermal alteration $\left(250-550{ }^{\circ} \mathrm{C}\right)$ in the form of albitization, dequartzification, and massive talc-chlorite deposits dated middle Aptian to early Turonian (117-92 Ma; Boutin et al., 2016, and references therein). Along its southern margin the North Pyrenean Zone includes the Metamorphic Internal Zone, a narrow (0.5-10-km-wide) area of hightemperature (HT)-low-pressure (LP) metamorphism affecting Mesozoic sedimentary rocks (Choukroune, 1974; Ravier, 1957; Ravier \& Thiébaut, 1982; Figure 1). The thermal perturbation is dated 113-85 Ma over the whole Pyrenean realm, encompassing a major phase of extension and associated magmatic activity (Golberg \& Leyreloup, 1990; Montigny et al., 1986, and references therein). Centimeter-scale fragments to kilometer-scale blocks of subcontinental mantle rocks and slices of granulitic crustal rocks occur throughout the Metamorphic Internal Zone, often associated with, or encased in, carbonate breccias (Azambre \& Ravier, 1978; Clerc et al., 2012; Lagabrielle et al., 2010; Lagabrielle \& Bodinier, 2008). It is argued that this zone represents an area of extreme crustal thinning, possibly hyperextension, where exhuming mantle provided the heat source that caused metamorphism of the overlying Mesozoic strata (Chelalou et al., 2016; Clerc \& Lagabrielle, 2014; Clerc et al., 2015, 2016; Vauchez et al., 2013). 


\subsection{The Agly-Salvezines Area}

\subsubsection{Structure and Stratigraphy}

The Agly Massif is a $\mathrm{N} 110^{\circ}$ trending lens-shaped half-dome ( $35 \mathrm{~km}$ by $8 \mathrm{~km}$ ), consisting in two main assemblages, hereafter referred to as the southern (mainly middle crust) and northern (middle-upper crust) compartments, separated by steep faults (Berger et al., 1993; Fonteilles et al., 1993; Figure 2). The Salvezines Massif outcrops as a $3 \mathrm{~km}$ by $2 \mathrm{~km}$ tectonic window trending $\mathrm{N} 110^{\circ}$ and represents the western continuation of the northern Agly compartment. Together, the two massifs are hereafter referred to as the Agly-Salvezines block.

The Agly Massif preserves the most complete, albeit tectonically reduced (less than 10-km-thick), section of Variscan crust outcropping in the Pyrenees (Barnolas et al., 1996, and references therein). The crustal section is characterized by an overall apparent tilting NNE of its northern, upper compartment that may be Variscan in age (Olivier et al., 2004, 2008). From south to north (or bottom to top) the massif consists of the following: (i) the granulite facies Caramany Unit (paragneisses, marbles, orthogneisses, granitoids; Precambrian-toLower Cambrian protoliths), typical of the base of the middle crust; (ii) the amphibolite facies Bélesta Unit (partly migmatized paragneisses, orthogneisses, granitoids, and pegmatites; Precambrian-to-Lower Cambrian protoliths), typical of the middle crust; and (iii) a metasedimentary cover of greenschist to amphibolite facies rocks (Cambro-Ordovician-to-Devonian protoliths), typical of the upper crust (Althoff et al., 1994; Berger et al., 1993; Delay, 1989; Olivier et al., 2004, 2008; Tournaire Guille et al., 2018). Plutonic intrusions include Lower-to-Middle Ordovician granitic laccoliths in the Paleozoic cover (Rivérole orthogneiss) and upper Carboniferous granitic bodies at the base of the Caramany Unit (Ansignan charnockite, 5-6 kbar, 20- to 23-km depth; Andrieux, 1982; Vielzeuf, 1996) and in the Paleozoic cover (Saint-Arnac granite, 5- to 10-km depth). Late Carboniferous plutonism is recognized to be closely linked to a well-known, albeit poorly dated, Carboniferous HT-LP metamorphism (e.g., Barnolas et al., 1996). The Salvezines Massif comprises from bottom to top the following: (i) upper Carboniferous granite and gneiss in its central and southern part and (ii) Devonian-Visean metasedimentary rocks in its NNW sector. Salvezines gneisses present facies and textural similarities to the Rivérole orthogneiss (Demange \& Pascal, 1979; Pascal, 1979).

The Agly-Salvezines block is surrounded by three N090 ${ }^{\circ}$-to-N110 ${ }^{\circ}$ trending regional synforms of Keuper to Apto-Albian strata (Figure 2; Fonteilles et al., 1993). (i) The Boucheville synform to the SSW, immediately north of the NPF, is separated from the oldest and highest-grade units cropping out along the southern edge of the Agly Massif by a very steep tectonic contact and from the southern Salvezines Mesozoic cover by a complex and highly deformed tectonic zone (Demange \& Pascal, 1979; Pascal, 1979) incorporating a 400-m-wide body of serpentinized mantle peridotite. (ii) The Bas-Agly syncline to the ENE is in tectonic contact with the Agly Massif on its southwesternmost limb. (iii) The Saint-Paul-de-Fenouillet synform to the north is overthrust by the Agly Massif on its southern limb and by the Bas-Agly syncline in the Tautavel region (Tautavel syncline).

\subsubsection{Mesozoic Metamorphism and Metasomatism}

The Bas-Agly and Boucheville synforms, which lie to the north and south of the Agly-Salvezines block (Figure 2), are assigned to the Metamorphic Internal Zone as both record HT metamorphism (400 to 600 C; Chelalou, 2015; Ducoux, 2017; Golberg \& Leyreloup, 1990; Vauchez et al., 2013). The most recent radiometric dating studies of this metamorphism in the Liassic-Albian strata (Albarède \& Michard-Vitrac, 1978; Golberg \& Maluski, 1988; Montigny et al., 1986) present ages of 95-90 Ma (late Cenomanian-late Turonian), coeval with magmatic activity in the Corbières region, further northeast. On the basis of RSCM paleotemperature data in the Boucheville synform, Chelalou et al. (2016) propose that temperature increases downward through the complexly folded and poorly dated succession, giving an estimated vertical geothermal gradient of $80^{\circ} \mathrm{C} / \mathrm{km}$ for the Cenomanian-Turonian peak HT-LP event. In contrast, in the simpler structure of the Bas-Agly syncline, highest temperatures are recorded in the youngest strata (Berriasian to Albian) with lower temperatures in older strata $\left(350-500{ }^{\circ} \mathrm{C}\right.$; Chelalou, 2015; Ducoux, 2017; Golberg \& Leyreloup, 1990; Vauchez et al., 2013) and underlying pre-Mesozoic rocks of the Agly Massif (maximum temperatures of $350^{\circ} \mathrm{C}$ in the Calce region, Figure 2; Clerc et al., 2015; Ducoux, 2017). Small pockets of lower Liassic to lowermost Cretaceous marbles, scapolite-bearing limestones, and breccias occur along fault zones within the Agly Massif itself (Berger et al., 1993; Fonteilles et al., 1993), recording temperatures as high as 400-450 ${ }^{\circ} \mathrm{C}$ (Serre de Vergès, Figure 2; Ducoux, 2017). In contrast, further north, the Barremian-Albian sediments of the Saint-Paul-de-Fenouillet syncline record markedly lower temperature metamorphism $\left(<260{ }^{\circ} \mathrm{C}\right)$ with temperatures increasing downward (Chelalou, 2015). No clear dating for this 
low-temperature metamorphism exists, so that it may be attributed either to synrift events or to Pyrenean orogenesis.

Albitization is almost exclusively confined to the northern Agly-Salvezines compartment (Boulvais et al., 2007; Pascal, 1979). Upper crustal granites of this compartment show hydrothermal alteration to albitite dated at 117-96 Ma (1.5-2 kbar and 350-450 ${ }^{\circ} \mathrm{C}$; Boulvais et al., 2007; Demange \& Pascal, 1979; Guinault et al., 2016; Pascal, 1979; Poujol et al., 2010). This precedes the Cenomanian-Turonian peak HT-LP event in the surrounding Boucheville and Bas-Agly synforms. The pressure conditions for albitization suggest a crustal depth of 5 to $8 \mathrm{~km}$. If one considers that temperature conditions correspond to background temperatures, estimates ranging from 40 to $90{ }^{\circ} \mathrm{C} / \mathrm{km}$ are derived for the geothermal gradient that prevailed over the Agly-Salvezines block during the Aptian to Cenomanian.

The reduced crustal profile of the Agly-Salvezines block has been alternatively interpreted as due to (i) late Variscan to post-Variscan extension, following either orogenic crustal thickening (Bouhallier et al., 1991) or transpressive thermal doming (Olivier et al., 2004, 2008), or (ii) Early Cretaceous extension based on directional similarities of basement stretching to Early Cretaceous stretching of the Agly Mesozoic cover (Delay, 1989; Delay \& Paquet, 1989; Paquet \& Delay, 1989; Paquet \& Mansy, 1991, 1992). While not favoring either interpretation, the work by R. Nicolas cited in Clerc et al. (2015) shows that partial (re)activation of Variscan mylonitic extensional shear zones under greenschist facies conditions in the southern Agly compartment $\left(300-400{ }^{\circ} \mathrm{C}, 2-3 \mathrm{kbar}\right)$ was synchronous with Early Cretaceous rifting. These pressure conditions suggest a crustal depth of 8 to $12 \mathrm{~km}$ for the Agly southern compartment, which is consistent with its expected structural position with respect to the northern granitic compartment at that time. However, if one considers that the temperature conditions of shear zone recrystallization correspond to background temperatures during the Early Cretaceous, this gives estimates of only $30-50{ }^{\circ} \mathrm{C} / \mathrm{km}$ for the geothermal gradient that prevailed over the Agly-Salvezines block. These estimates are lower than but overlapping with those obtained for albitization in the northern Agly-Salvezines compartment over the same period of time.

3.3.3. Thermal State of the Agly-Salvezines Block at Onset of Pyrenean Convergence

Although the Agly Massif lies between two sectors of the Metamorphic Internal Zone, which both record temperatures of up to $500-600{ }^{\circ} \mathrm{C}$, the basement rocks of the massif did not record any post-Variscan temperature higher than the greenschist facies temperature conditions reached during the Variscan. Moreover, the vertical geothermal gradient that prevailed specifically over the Agly-Salvezines block during the Early Cretaceous (rifting, albitization, and mylonitic reactivation) is poorly constrained, with overall estimates ranging from 30 to $80^{\circ} \mathrm{C} / \mathrm{km}$ and varying between the northern and southern compartments.

Many processes have been proposed as the heat source for HT conditions recorded in Mesozoic strata: (i) exhumed mantle (Clerc \& Lagabrielle, 2014; Clerc et al., 2015, 2016; Chelalou et al., 2016; Vauchez et al., 2013), and/or (ii) high thermal fluxes along deeply rooted strike-slip faults (Clerc et al., 2015, 2016; Vaudin, 1982), and/or (iii) heat transfer by fluid circulation (Boulvais, 2016; Clerc et al., 2015, 2016; Dauteuil \& Ricou, 1989). Along with evidence of extensional shear zones possibly active during the Cretaceous on the northern side of the Agly Massif (Paquet \& Mansy, 1991), the reduced crustal section of the Agly Massif, and the presence of a block of mantle peridotite in the Boucheville synform, these features have led recent workers to position the Agly-Salvezines block at the distal edge of the Aptian-Cenomanian rift system, where deep crustal levels and subcontinental mantle rocks were exhumed (Chelalou et al., 2016; Clerc et al., 2016; Clerc \& Lagabrielle, 2014; Ducoux, 2017; Vauchez et al., 2013). While all models of these authors consider the Boucheville and Bas-Agly synforms as autochtonous depocenters to the north and south of the Agly Massif, they differ in that they propose either (i) unroofing of the Agly-Salvezines basement by Albian times (Clerc \& Lagabrielle, 2014; Ravier, 1957; Vauchez et al., 2013) or (ii) burial of the massif below a continuous and thick Apto-Albian depocenter (Chelalou et al., 2016; Clerc et al., 2015, 2016; Ducoux, 2017; Olivier, 2013). The former implies that the allochthonous Agly Mesozoic cover in the Calce region has been almost fully preserved since the Albian. In contrast, the latter is supported by the absence of any recorded clasts of Mesozoic or pre-Mesozoic lithologies in the upper Aptian-to-lower Cenomanian fine-grained distal clastic marine sediments in either the Bas-Agly or Saint-Paul-de-Fenouillet depocenter that could have been locally derived from the emerging massif (Berger et al., 1993). It also favors the proposition of Clerc and Lagabrielle (2014) who argue that Albian sediments in Bas-Agly and Boucheville experienced HT conditions below a possibly 3- to 6-km-thick cover of Albo-Cenomanian flysch. As 
highlighted by Olivier (2013), currently available field and geochemical data do not allow a conclusive decision on this point.

New data are therefore required to constrain the structural and thermal evolution of the Agly-Salvezines block during early orogenesis and to define the thermal state of the crustal block before the onset of orogenesis. If the block was part of the distal margin of an Aptian-Cenomanian rift system, possibly hyperextended, we would expect rift-related heating and subsequent postrift cooling. However, we do not know the depth of burial of the Agly-Salvezines block during the Early Cretaceous, nor do we know the extent of the HT-LP metamorphic event affecting the block. With low-temperature thermochronology we aim to distinguish between burial below a thin sedimentary cover (relatively cold signature) or a thick cover (relatively hot signature). We also aim to get a better sense of background temperatures through time and investigate whether the Early Cretaceous metamorphism was focused in fault zones and/or localized in certain areas. The data presented in this study aim to answer some of these critical issues regarding the rift-to-collision transition.

\section{4. (U-Th)/He Thermochronology Analyses}

\subsection{Sampling Strategy}

We collected a total of 17 samples from the Agly and Salvezines massifs: 10 granitic samples, mostly in the northern, upper compartment, and 1 detrital and 6 gneissic samples in the southern, lower compartment (Figure 2). Four granitic samples (15-AG-08, NP15-AM-A07, NP15-AM-A08, and NP15-AM-A10) were collected in the Upper Carboniferous Saint-Arnac granite pluton in order to document the top, center, and base of the pluton (Olivier et al., 2004, 2008). Three samples with similar facies (G3, G4 and G5) were collected in the Salvezines albitized granite pluton. Sample 15-AG-01 was collected from sillimanite- and muscovitebearing Ordovician micaschists, and sample 15-AG-07 was collected in the Rivérole orthogneiss. Four samples were collected in the Bélesta Unit: samples C13MA-1B and 15-AG-06 are gneissic, and samples NP15-AM-A11 and 15-AG-02 present granitic textures. Finally, three gneissic samples (C13MA-2A, 15-AG-03, and 15-AG-04) were collected in the Caramany Unit, and sample 15-AG-05 was collected in the Upper Carboniferous Ansignan charnockitic pluton.

\subsection{Zircon (U-Th)/He Methodology}

Zircon grains from the 50- to $250-\mu \mathrm{m}$ fraction were isolated for (U-Th)/He dating analyses using conventional mineral separation techniques, including crushing, grinding, sieving, and water table concentration, standard heavy-liquid density, and magnetic susceptibility separation techniques. Zircon grains were subsequently handpicked for analysis according to the following conditions: (i) of bipyramidal shape (euhedral), unbroken and visibly fracture free, (ii) of any size (length, width, and thickness) $>60 \mu \mathrm{m}$, (iii) of any transparency/opacity, and (iv) inclusion free when inspected under a binocular microscope.

The (U-Th)/He dating method is based on the radioactive decay of ${ }^{238} \mathrm{U},{ }^{235} \mathrm{U}$, and ${ }^{232} \mathrm{Th}$ (decay series) into ${ }^{4} \mathrm{He}$ or alpha particles. Conventional bulk single-grain ZHe analyses were performed conjointly at the Centre de Recherches Pétrographiques et Géochimiques (CRPG; Nancy, France) and at the UTChron facilities at the Jackson School of Geosciences (University of Texas, Austin, USA). A bulk (U-Th)/He age is derived from measurements of parent and daughter nuclide abundances in a single, entire crystal (aliquot). It must be acknowledged that as is typical for most, if not all, conventional bulk ZHe dating studies, the degree of zonation within each of our dated grains was not measured due to intrinsic analytical protocol limitations. This will be discussed in section 5. Nine samples were analyzed at the CRPG following procedures described in Pik et al. (2003) and Godard et al. (2009) for ${ }^{4} \mathrm{He}$ extraction and Tibari et al. (2016) for bulk parent U, Th, and Sm concentration measurements. The other eight samples were analyzed at the Jackson School of Geosciences following the procedures described in Wolfe and Stockli (2010). Based on replicate analysis of the Fish Canyon Tuff ZHe age standard, analytical uncertainties arising from the two protocols for uncorrected ZHe ages are estimated at $6 \%(1 \sigma)$ and $4 \%(1 \sigma)$, respectively.

Given the traveling distances of ${ }^{4} \mathrm{He}$ or alpha particles produced by radioactive decay of ${ }^{238} \mathrm{U},{ }^{235} \mathrm{U}$, and ${ }^{232} \mathrm{Th}$ ( 16.7, 19.6, and $\sim 19.3 \mu \mathrm{m}$, respectively; Farley et al., 1996), these particles can be ejected from the outer $\sim 20 \mu \mathrm{m}$ of the grain. As a result, ZHe ages were morphometrically corrected for alpha-ejection (the ejection correction parameter $\mathrm{F}_{\mathrm{T}}$ ) according to Ketcham et al. (2011). We considered our zircon grains as equidimensional bipyramidal solids, with width, $a$, equal to thickness, $b$, and the number of pyramids, $N p$, equal to 2 . 
Polynomial fit parameters for surface-area-to-volume ratio, $\beta$, were those of Hourigan et al. (2005) for prisms with pyramids. As the Agly-Salvezines rocks are known to have experienced Carboniferous HT-LP metamorphism, we expected ZHe ages younger than $500 \mathrm{Ma}$. Therefore, we considered that the contribution of ${ }^{235} \mathrm{U}$ to the total ${ }^{4} \mathrm{He}$ concentration measured was negligible, and we decided to keep using $\mathrm{F}_{\mathrm{T}}$ as the linear correction to the measured age as expressed by Farley et al. (1996).

\subsection{Apatite (U-Th)/He Methodology}

After mineral separation, apatite grains were handpicked for analysis according to the following conditions: (i) hexagonal shape (euhedral), unbroken and visibly fracture free, (ii) of sufficient size (width and thickness) $>70 \mu \mathrm{m}$, and (iii) absolutely inclusion free when carefully inspected under a binocular microscope at $\times 180$ immersed in alcohol. Selection of apatite absolutely free of $U$ - and Th-bearing inclusions represents the biggest hurdle to accurate and reliable AHe age determinations. All conventional single-grain AHe analyses were performed at the UTChron facilities at the University of Texas, following procedures described in Prior et al. (2016).

Similar to ZHe ages, AHe ages were corrected morphometrically for alpha-ejection ( $\mathrm{F}_{\mathrm{T}}$ correction) according to Ketcham et al. (2011) due to long attenuation distances of radiogenic ${ }^{4} \mathrm{He}$ or alpha particles produced from ${ }^{238} \mathrm{U},{ }^{235} \mathrm{U}$, and ${ }^{232} \mathrm{Th}(\sim 19.7, \sim 22.8$, and $\sim 22.5 \mu \mathrm{m}$, respectively; Farley et al., 1996). After in vacuo totalfusion degassing by UV-laser heating for $5 \mathrm{~min}$ at $1070{ }^{\circ} \mathrm{C}$ and cryogenic purification, ${ }^{4} \mathrm{He}$ concentrations of single-grain apatite were determined using quadrupole mass spectrometry by isotope dilution $\left({ }^{3} \mathrm{He}\right.$ spike). Degassed apatite aliquots are retrieved, dissolved in 30\% nitric acid, spiked with an isotopically enriched tracer, and analyzed for U, Th, and Sm concentrations using a Thermo Element2 inductively coupled plasma mass spectrometer fitted with a microcentric nebulizer. Based on replicate analysis of the Fish Canyon Tuff AHe age and other fast-cooled in-house volcanic apatite standards, analytical uncertainties for uncor-

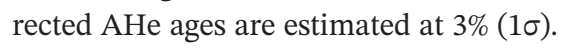

\section{5. (U-Th)/He Results}

Our 17 samples provided a total of 94 zircon crystals satisfying the suitability tests for further investigation. Three of these samples also provided two suitable apatite crystals each. Our (U-Th)/He data are reported in Data Set $\mathrm{S} 1$ in the supporting information. Zircon grains yield $\mathrm{F}_{\mathrm{T}}$-corrected He ages ranging from $39.0 \pm 2.3$ to $117.1 \pm 7.0 \mathrm{Ma}$ with intrasample grain age variation from $\sim 19 \%$ to $\sim 93 \%$. Our $\mathrm{AHe}$ ages range from $40.1 \pm 2.4$ to $55.0 \pm 3.3 \mathrm{Ma}$. ZHe ages older than the Paleocene account for $\sim 87 \%$ of the Agly-Salvezines data set. Ten samples yield middle Aptian to late Turonian (117-90 Ma) ZHe ages, hereafter referred to as middle Cretaceous ages. These ages account for $\sim 22 \%$ of the data set. Only 2 zircons ( $2 \%$ of the data set) yield Eocene ages, which fall into the range of our AHe ages and the AFT ages of Yelland (1991) and Gunnell et al. (2009) for the Agly Massif $(40.3 \pm 2.6$ to $49.0 \pm 1.8 \mathrm{Ma}$ for mean track lengths of 13.19-14.18 $\mu \mathrm{m}$ ).

Our ZHe and AHe data set shows a high degree of age variability due to significant intrasample variation, which is larger than would be expected given the analytical precision. It has been demonstrated that this could result from the inability of a single set of kinematic parameters for He diffusion to describe the natural thermochronometric behavior of zircon (Cherniak et al., 2009; Guenthner et al., 2013; Ketcham et al., 2013; Reiners et al., 2002, 2004) and apatite (Flowers et al., 2007; Gautheron et al., 2009; Shuster et al., 2006). Grain-specific characteristics such as grain size, parent nuclide zoning, and radiation damage are among the most important known factors that influence helium diffusivity, all the more exacerbated in zircon (Dobson et al., 2008; Guenthner et al., 2013; Hourigan et al., 2005; Reiners et al., 2004; Wolfe \& Stockli, 2010). It is therefore not unreasonable to expect outliers for crystals with very low helium retentivity. As the two Eocene ZHe ages fall into the range of both previously published AFT data and our AHe data, they are considered as outlier data points and will subsequently be ignored.

Systematic correlations between ZHe ages and equivalent spherical radius (an approximation of grain size) are not apparent in any of our individual sample zircon data sets (Figure S1 in the supporting information). Although no clear relationships between these two variables are found for zircon, we will nevertheless consider the grain size effect in later discussions. Regarding our AHe ages, it is not reasonable to search for any correlation with only two ages per sample, and we will therefore focus mainly on zircon ages. Given that 
zonation of $U$ and $T h$ is a potential source of age variation that has its strongest effect for grains with an $\sim 60 \mu \mathrm{m}$ equivalent spherical radius when high eU cores or high eU rims occupy the inner or outer third of the grain, respectively (the zircon impact index/factor/number; Guenthner et al., 2013, 2015), our lack of observations of zircon zonation for grains with a similar equivalent spherical radius on average $(\sim 65 \mu \mathrm{m})$ may appear to be an issue. In particular, Tournaire Guille et al. (2018) have recently shown that typical zircons collected from some of our sample locations show pre-Variscan-inherited cores and Upper Carboniferous metamorphic overgrowths that may occupy one third of the grains. However, Odlum and Stockli (2017), who analyzed zircons from eight of the samples presented in our study for U/Pb dating (solid triangles in Figures 2 and 3), show that zircon zonation is only observed in gneissic samples 15-AG-06 and 15-AG-03. In addition, the $U$ and Th abundance data for zoned grains presented in the two previously mentioned studies give a good sense of the style of zonation in all the grains analyzed. First, very few metamorphic overgrowths have been documented in typical zircons collected from the igneous sample locations. Second, these data indicate rim eU enrichment of less than an order of magnitude on average for zoned grains in the Bélesta and Caramany units, therefore likely placing the level of zonation for our equivalent grains between the "mildly problematic and worst case" scenarios of Guenthner et al. (2015; factor of enrichment of 2 and 10, respectively, for zircon grains systematically zoned in the same fashion with high eU rims occupying the outer third of the grain). These observations suggest that heterogeneous distribution of $U$ and Th in our zircons, albeit likely contributing to some of the observed age irreproducibility in each sample, cannot alone explain the large spread in our ZHe ages. The remainder of this results section, and more generally this study, will therefore be mainly focused on the third main source of age variation in our ZHe data set: radiation damage (Guenthner et al., 2013, 2014, 2015, 2017).

Single-grain He ages are plotted against the bulk effective uranium concentration, eU, in Figure $3 a$ (eU $[\mathrm{ppm}]=\mathrm{U}[\mathrm{ppm}]+0.235 * \mathrm{Th}[\mathrm{ppm}])$. Bulk eU is calculated for each grain, providing a proxy for both the production rate of alpha particles from decay of $U$, Th, and their daughter products (Sm being a minor contributor to the alpha particle production budget) and the relative amount of radiation damage accumulated in each crystal of a sample that has not experienced annealing (for apatite: Flowers et al., 2007; Shuster et al., 2006; for zircon: Guenthner et al., 2013).

Our AHe ages are older at higher bulk eU. The age variability in our AHe data set is similar to that previously reported in other geological settings (Gautheron et al., 2009, and references therein). In particular, AHe ages at high eU concentrations may be found to be as old as or even a little older than AFT ages for the same geological province. It has been demonstrated that alpha-recoil damage induced by recoil of $U$ and Th decay series during emission of alpha particles and eU concentration govern He diffusion within apatite crystals, and thus the resulting AHe ages (Flowers et al., 2007; Gautheron et al., 2009; Shuster et al., 2006). The amount of alpha-recoil damage increases with eU, enhancing He retention for apatite crystals with higher eU and extending crystal temperature sensitivity from $\sim 40-80{ }^{\circ} \mathrm{C}$ (Crowley et al., 2002; Farley, 2000; Farley et al., 1996; Stockli et al., 2000) up to (sometimes even higher than) that of the AFT system ( 100 ${ }^{\circ} \mathrm{C}$; Gallagher et al., 1998).

Similar age variability to that in our ZHe data set is reported in other data sets from the Pyrenees and from other similar orogenic settings (e.g., Guenthner et al., 2014, 2015, 2017; Vacherat et al., 2014, 2016). It has been demonstrated that this results from the inability of a single set of kinematic parameters for He diffusion to describe the natural thermochronometric behavior of zircon (Cherniak et al., 2009; Guenthner et al., 2013; Ketcham et al., 2013; Reiners et al., 2002, 2004). In particular, Guenthner et al. (2013) have recently proposed that such age variation in data sets illustrates the damage-dependent sensitivity of He in zircon to thermal processes. Similarly to the AHe system, these authors have established a zircon radiation-damage and annealing model that quantitatively describes the effects of radiation damage on He diffusion in zircon as a function of time and temperature. They show the clear dependency of He diffusivity on radiation damage by parameterizing the relationship between damage and diffusivity. Their model considers a partial annealing zone of $310-22{ }^{\circ} \mathrm{C}$ and the 8-orders-of-magnitude variation in diffusivity across the radiation dose spectrum. It also integrates the damage-based diffusion kinetics to calculate ZHe closure temperature as a function of the alpha dose. The model thus predicts that the ZHe system in damaged zircons (damage amounts ranging from $1 \times 10^{16}$ to $1 \times 10^{18} \mathrm{\alpha} / \mathrm{g}$ ) is sensitive to temperatures of 140 to $200-250{ }^{\circ} \mathrm{C}$. This is in good agreement with previously documented temperature ranges for the ZHe partial retention zone (Reiners et al., 2002; Stockli, 2005; Tagami et al., 2003; Wolfe \& Stockli, 2010). 

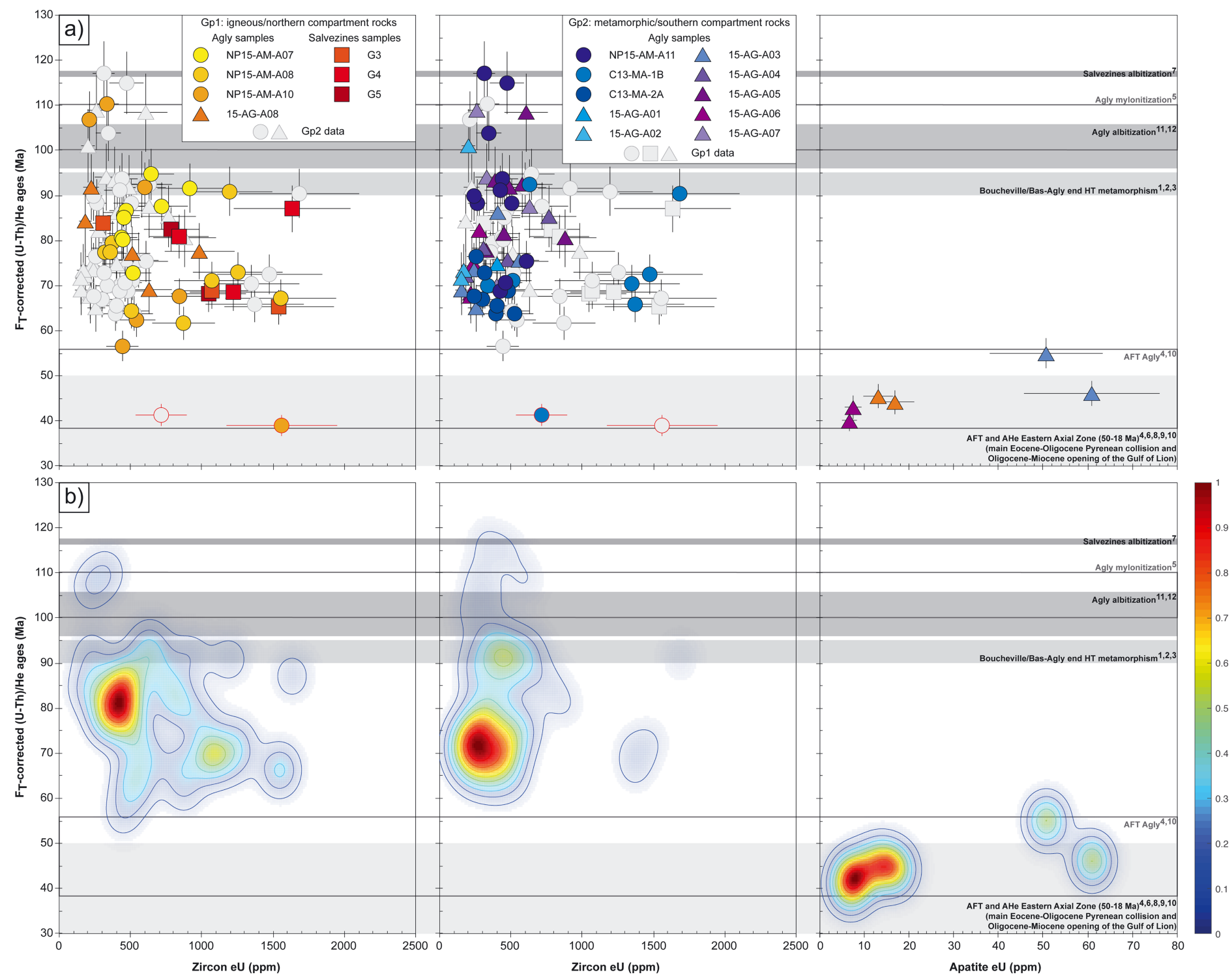

Figure 3. (a) Zircon (left and middle inserts) and apatite (right insert) He age-eU correlations for the Agly-Salvezines data set, divided with the sample and group color scheme used in Figure 2. ZHe age data for Gp1 and Gp2 are plotted separately. Gray bars indicate the ages of major thermal and structural events from literature. (b) Density graphs of the single-grain (U-Th)/He ages obtained in this study (2-D Kernel density estimation via the Parzen-Rosenblatt window method). 1: Albarède and Michard-Vitrac (1978); 2: Montigny et al. (1986); 3: Golberg and Maluski (1988); 4: Yelland (1991); 5: work by R. Nicolas cited in Clerc et al. (2015); 6: Maurel (2003); 7: Boulvais et al. (2007); 8: Denèle (2007); 9: Maurel et al. (2008); 10: Gunnell et al. (2009); 11: Poujol et al. (2010); 12: Guinault et al. (2016).

In the case of ZHe thermochronology, age-eU plots have recently proved to be very useful to gain insight into the thermal history of a sample or a group of samples in several studies. It has been demonstrated that a sample or a group of samples may yield specific age-eU correlations, positive or negative, even both, as a result of its entire thermal history (e.g., Anderson et al., 2017; Guenthner et al., 2013, 2014, 2015, 2017; Hart et al., 2017; Johnson et al., 2017; Powell et al., 2016; Thomson et al., 2017; Vacherat et al., 2014, 2016). In our He age-eU plots (Figure 3) we split the Agly-Salvezines sample collection into two distinct sample groups ( $\mathrm{Gp} 1$ and $\mathrm{Gp} 2$ ) based on the sample rock type (igneous or metamorphic) and sample location (or inferred pre-Early Cretaceous sample depth: northern, upper compartment versus southern, lower compartment), irrespective of either the intrasample variation criterion or grain characteristics. This aimed at separating rocks that had, as a first approximation, distinct pre-Early Cretaceous history and therefore crystals with distinct grain-specific characteristics. Considerations of eU and sample groups are discussed 
in more detail in later sections. Error bars shown here represent the $1 \sigma$ analytical uncertainty for each singlegrain aliquot. Results for the two massifs, Agly and Salvezines, are presented together.

The first group (Gp1) comprises the seven igneous samples located in the northern compartment of AglySalvezines (Figure 2). It is characterized by ZHe ages ranging from $56.6 \pm 3.4$ to $110.2 \pm 6.6 \mathrm{Ma}$. Intrasample age variability is the same as that of the whole ZHe data set. ZHe ages are associated with bulk eU concentrations ranging from 183 to $1,633 \mathrm{ppm}$. Individual age and eU ranges are similar in the error bars from one sample to another, with the exception of sample NP15-AM-A10, which yields the oldest (AptoAlbian) ZHe ages for this group. Four samples (NP15-AM-A10, 15-AG-08, G3, and G5) have a clear negative age-eU correlation as ages decrease from $\sim 90 \pm 5$ Ma to $\sim 65 \pm 5$ with increasing eU (Figure S2). Sample NP15-AM-A07 may have a positive age-eU correlation, as ages increase from $\sim 75 \pm 5$ Ma to $\sim 95 \pm 5$ with increasing eU.

The second group (Gp2) comprises the 10 samples from the southern compartment of Agly (Figure 2). Both the intrasample grain variations and the ZHe age range of these samples are similar to those of Gp1 (age variability of $\sim 19 \%$ to $\sim 71 \%$; ages of $63.8 \pm 3.8$ to $117.1 \pm 7.0 \mathrm{Ma}$ ). Nonetheless, the ZHe age range is mostly confined to relatively low bulk eU concentrations (152-879 ppm) and a larger proportion of ages clustering around 60-75 Ma is found compared with Gp1. Five samples (15-AG-02, 15-AG-03, 15-AG-04, 15-AG-05, and 15-AG-06) have a positive age-eU correlation as ages increase from $\sim 70 \pm 5$ to $\sim 100 \pm 5$ Ma with increasing eU (Figure S2). Three samples (NP15-AM-A11, C13-MA-2A, and 15-AG-07) may have a negative ageeU correlation.

Second-order scatter along the dominant age-eU trends is observed and likely results from the combined effects of grain size and, more importantly, intragranular $U$ and Th heterogeneities within each grain. Nonetheless, it is clear that samples from the same group show similar individual zircon eU ranges and age-eU correlations (first-order negative correlations for Gp1 samples and positive correlations for Gp2 samples). We therefore argue that all samples of $\mathrm{Gp} 1$ experienced the same thermal history since the $\mathrm{ZHe}$ clock started. The same can be concluded for all samples of $\mathrm{Gp} 2$.

For each group, we combined individual sample data sets into a group data set and generated a twodimension (age and eU) kernel density estimation of the data (Figure 3b). The statistical distribution of Gp1 ages (37 ZHe ages) highlights two significant age clusters. The main age cluster (80 Ma) is found at eU concentrations of $\sim 400 \mathrm{ppm}$. The second age cluster (70 Ma) corresponds to zircon crystals with eU concentrations ranging from $\sim 1,000$ to $\sim 1,600 \mathrm{ppm}$. An additional age cluster, although poorly defined, may be centered on $110 \mathrm{Ma}$ and 300-400 ppm. The age distribution in Gp2 (55 ZHe ages) suggests two age clusters at low eU concentrations $(<500 \mathrm{ppm})$. The main cluster is found around $70 \mathrm{Ma}$ at eU concentrations of $\sim 300 \mathrm{ppm}$. The second cluster is centered on 90-95 Ma and eU concentrations of $\sim 500 \mathrm{ppm}$. This cluster may be argued to encompass ages ranging from 90 to $117 \mathrm{Ma}$. An additional age cluster, although poorly defined, may be centered on $70 \mathrm{Ma}$ and $1,500 \mathrm{ppm}$, corresponding to the rare ZHe ages plotting at high eU (>1,000 ppm). Both sample groups yield overlapping single-grain ZHe ages over the whole spread in bulk eU concentrations. Although 82-95\% of ages from the Gp1 data set are younger than 90-95 Ma (compared with 64-79\% for Gp2), arguing for distinct maximum ZHe ages of Gp1 and Gp2 is hazardous. Age distributions (Figure $3 \mathrm{~b}$ ) do show an age cluster centered on 117-90 Ma (eU of $\sim 300-500 \mathrm{ppm}$ ) for both groups. The situation is the same for most of ZHe ages around 65-75 Ma at low eU ( 300-400 ppm) for Gp2 compared with Gp1 and around $70 \mathrm{Ma}$ at high eU (1,000-1,500 ppm) for Gp1 compared with Gp2. These clusters are the cornerstones of the overall ZHe age-eU correlations observed for each group. First, these slight proportional differences could simply be the result of undersampling. Second, Odlum and Stockli (2017) and Tournaire Guille et al. (2018) have shown that incorporation of $U$ and Th into zircon grains of the Agly Massif depends on the complexity of the grain crystallization history. In particular, typical zircons collected from the southern sample locations show systematic rim eU enrichment, so that they may have distinct domains with variable radiation damage, and therefore variable diffusivities. Consequently, this not only suggests that the ages these grains yield will be more dispersed or randomly distributed than ages of unzoned grains (igneous, northern compartment), but it also implies that they will probably plot at lower eU than their counterparts. One has then statistically more chance of handpicking zircon crystals with low bulk eU concentrations (or less chance in case of high bulk eU) in rocks from the southern compartment than in plutonic rocks from the northern compartment. Taken together, these two arguments could explain the 
better documentation of positive age-eU correlations for $\mathrm{Gp} 2$ and the poorer documentation of negative correlations in Gp1. On another note, based on the Guenthner et al. (2013) model, one can expect older crystals with longer exhumation histories to accumulate more radiation damage in the absence of annealing, shifting maximum retentivity for $\mathrm{He}$ and associated older $\mathrm{ZHe}$ ages at lower eU concentrations. All our samples yield older ages at similar bulk eU concentrations, most likely indicating homogeneous annealing $\left(310-223{ }^{\circ} \mathrm{C}\right.$ and above) of radiation damage of zircons at some point in their thermal history (the Variscan orogeny and the Aptian-middle Cenomanian HT-LP event are the best candidates; see below). We therefore argue that the reverse trends of age-eU correlations for $\mathrm{Gp} 1$ and $\mathrm{Gp} 2$ do not necessarily arise from distinct thermal histories for the two groups but may be simply due to some kind of sampling bias, as described above. The age clusters at low eU ( 300-400 ppm) around $70 \mathrm{Ma}$ for Gp2 and 80 Ma for Gp1 are most likely equivalent, possibly suggesting that rocks lying at different depths reached a particular closure temperature depth with some 10 myrs of delay. In a wider perspective, our AHe ages are very close to each other and display as a whole a positive age-eU correlation, consistent with apatite radiation-damage and annealing models. On the basis of all the low-temperature thermochronology similarities presented by the two groups, we expect all samples from this study to have experienced the same thermal history, at least since the middle Cretaceous.

\section{Numerical (U-Th)/He Age Modeling}

Recent studies (e.g., Anderson et al., 2017; Guenthner et al., 2014, 2015, 2017; Johnson et al., 2017; Powell et al., 2016; Vacherat et al., 2014, 2016) have shown that numerical modeling, incorporating apatite and zircon radiation-damage and annealing models for both the fission track and (U-Th)/He systems, is extremely valuable for understanding and interpreting data. It allows exploration of the response of different thermochronometers to various thermal histories and ultimately provides more quantitative constraints on the thermal history of a sample. To constrain the range of plausible $t$ - $T$ paths producing either model age-eU correlations or single-grain He ages that most closely match the data presented in this study, we performed both inverse modeling and forward modeling using the software program HeFTy (Ketcham, 2005).

\subsection{Data Inverse Modeling Approach Using HeFTy}

The new ZHe and AHe data presented in this study complete, and agree with, the sparse AFT data obtained by Yelland (1991) and Gunnell et al. (2009) for the Agly-Salvezines block. Altogether, these data document the time-temperature history of the crustal block in the overall temperature range of $45-250{ }^{\circ} \mathrm{C}$ (lower bound of the AHe partial retention zone-upper bound of the ZHe partial retention zone; e.g., Guenthner et al., 2013; Stockli et al., 2000).

\subsubsection{HeFTy Thermochronology Model Parameterization}

To explore plausible $t$ - $T$ spaces consistent with our data, we first used the inverse modeling approach. The number of thermochronometric models that can be input into HeFTy for inverse modeling is relatively limited. In particular, as already mentioned in Vacherat et al. (2014) and Powell et al. (2016), the full range of single-grain eU-dependent $\mathrm{He}$ ages cannot be used, so that representative individual $\mathrm{ZHe}$ and AHe ages must be chosen. All the model inputs and constraints used for our inverse modeling simulations are reported in Table S1, following the model input reporting protocol of Flowers et al. (2015).

Three ZHe age-eU couples were used as parameterizations of three HeFTy ZHe models, each of them representing one of the three age clusters shared by the two groups. The first cluster is defined around $75 \mathrm{Ma}( \pm 9.4 \mathrm{Ma}, 12 \%, 2 \sigma$ analytical uncertainty) at low eU concentrations (300-500 ppm; HeFTy ZHe model 1). The second cluster concerns $\mathrm{ZHe}$ ages around $70 \mathrm{Ma}( \pm 12 \%, 2 \sigma$ analytical uncertainty) at relatively high eU concentrations (1,500 ppm; HeFTy ZHe model 2). The last cluster represents middle Cretaceous ages (105 Ma, $\pm 12 \%, 2 \sigma$ analytical uncertainty, 400 ppm; HeFTy ZHe model 3). A similar reasoning was applied for AHe data with two AHe models characterizing ages either at low or at high eU concentrations (HeFTy AHe models 1 and 2). Finally, two AFT models were considered, based on Gunnell et al. (2009; HeFTy AFT models AGLY1 and AGLY5).

To reproduce the range of our ZHe ages ( $\sim 70-110 \mathrm{Ma})$, our AHe ages ( $\sim 3-50 \mathrm{Ma})$, and published AFT ages ( 40-50 Ma), the post-Barremian time-temperature history was first left free within a $t$ - $T$ space limited by the upper bound of the partial annealing zone of the Guenthner et al. (2013) model $\left(\sim 300{ }^{\circ} \mathrm{C}\right)$ and surface 
temperature (shallow- to middle-crustal temperatures). The number of thermal constraints was then increased and $t-T$ space limits modified according to the results of the first inverse modeling simulation to see whether this helps the software to search $t$ - $T$ paths consistent with our data.

\subsubsection{Inverse Modeling Results}

After randomly testing 300,000 $t-T$ paths, the HeFTy software clearly fails to return thermal histories consistent with the required inputs (no acceptable or good solutions). In our case, such a failure occurs when more than five HeFTy inputs are used. The comparison of our AHe age data with the AFT age data present in the literature for the Agly Massif indicates that the AHe system encompasses a larger range of crystal temperature sensitivities than does the AFT system in this geological province. Therefore, we chose to keep performing inverse modeling with the five $\mathrm{ZHe}$ and AHe models only. Results of the first inverse modeling simulations are presented in Figure S3.

The modeling returned only 142 acceptable and 4 good solutions. All the $t-T$ paths obtained show that heating had to occur between 200 and 70-60 Ma, followed by rapid cooling. However, the timing of transition from heating to cooling is poorly constrained by inverse modeling. Overall, good fits place the onset of cooling around $60 \mathrm{Ma}$, whereas acceptable fits show a large range of possibilities (100-60 Ma). This result further illustrates that the pre-Eocene thermal history experienced by individual zircons is a variable that is difficult to constrain a priori in our data set. Nonetheless, these differences are intimately linked to the maximum temperature reached in the Cretaceous (and the total amount of heating). The good solutions involve a minimum temperature increase $\left(\sim 120^{\circ} \mathrm{C}\right)$ and a fairly low heating rate $\left(1^{\circ} \mathrm{C} / \mathrm{Ma}\right)$, but a large proportion of acceptable solutions suggest that heating may have generated temperatures as high as the upper bound of the partial annealing zone of the Guenthner et al. (2013) model in the Early Cretaceous (relatively short-lived heat pulse). This second result is striking on two aspects. First, the good $t$ - $T$ paths show that peak temperatures are not reached before the Late Cretaceous, which seems counterintuitive with regard to the HT conditions recorded by sediments in the Early Cretaceous. Second, a non-negligible number of paths do predict peak temperatures over the period that saw HT-LP metamorphism and/or hydrothermal alteration in the study area, but they only present an acceptable fit to the data. We therefore further constrained the software to search $t$ - $T$ paths incorporating an increasing number of thermal constraints during the Cretaceous (Figure S3). To envision scenarios in which any heat pulse occurring in the Early Cretaceous may have been strong (peak temperatures higher than the ZHe partial retention zone, as constrained with the RSCM technique or estimated for albitization) but short-lived enough not to reset appreciably the $\mathrm{ZHe}$ system, we also ran simulations that allowed the software to search $t$ - $T$ paths within larger $t$ - $T$ spaces for the post-Barremian time-temperature history (Figure S4).

The second generation of inverse modeling returned very few good solutions for each set of simulations. On the one hand, good fits obtained when increasing parsimoniously the number of constraints without contradicting geological observations (Figure S3) show more rapid heating up to the ZHe partial retention zone in the Early Cretaceous and also more rapid cooling in the Late Cretaceous. The acceptable fits of representative data with a more complex model suggest that the data may not exclude a short-lived heating pulse in the Early Cretaceous. Nonetheless, it should be acknowledged that this approach is close to the forward modeling approach that would consider the whole data set. For this reason, we performed more detailed forward modeling of our ZHe data that we present in the next section. On the other hand, the good $t$ - $T$ paths found over a larger, allowed temperature range in the Cretaceous are similar in every respect to those obtained when peak temperatures are not allowed to exceed the upper bound of the partial annealing zone of the Guenthner et al. (2013) model in the Cretaceous. In this set of simulations, the timing of transition from heating to cooling is no better constrained, again spanning the 100- to 60-Ma time range. A negative result is obtained if the number of constraints is increased, leading to fewer to no good $t-T$ paths. Nonetheless, all $t-T$ paths found further highlight the fact that the higher the peak temperature is in the Cretaceous, the earlier or shorter-lived the heat pulse has to be to fit the data. By doing so, the predicted ZHe age variability is always lower than the input ZHe age variability, with younger ages at intermediate eU and older ages at low and high eU. Yet the input age variation results from our choice of representative ages, so that it is itself already lower than that in our whole ZHe data set.

Taken together, these observations therefore suggest the peak temperatures proposed in the literature for both the HT-LP metamorphic event and albitization/shear zone recrystallization most likely do not reflect the background temperatures that existed in the Agly-Salvezines crustal block. In particular, if these 
maximum temperatures existed, they would have been very short-lived (less than 20 myrs) and probably localized as hydrothermal activity in fault zones. For this reason, we do not further simulate this option with forward modeling.

\subsection{ZHe Data Forward Modeling Approach Using HeFTy}

Guenthner et al. (2013) have shown that first-order correlations between age and eU for single samples are highly valuable to constrain thermal histories. As the degree of radiation damage in a crystal is a function of alpha production and annealing, themselves functions of the crystal's eU concentration and thermal history, each crystal from a single sample will act as an individual thermochronometer with its own temperature sensitivity, helium diffusivity (or retentivity), and (U-Th)/He age. As long as it is impossible to describe the full range of single-grain $\mathrm{ZHe}$ ages of a data set (specific to a single sample or a collection of samples with the same thermal history as expected here) in HeFTy, pertinent information on burial temperatures and cooling rates will probably be removed, making it impossible to properly constrain thermal histories. We therefore expect the forward modeling approach to better recognize the complexity manifested in our ZHe ageeU correlations.

\subsubsection{Thermal Histories Tested}

Given the thermal histories returned by inverse modeling, we used the forward modeling approach to produce zircon age-eU predictions for two distinct geologically plausible $t$ - $T$ paths from 305 Ma to present (first and second families; Figures 4, 5, S5, and S6). Any specific characteristics of one or other family are described in next sections. These $t$ - $T$ paths represent a wide range of sensitivity for the ZHe system and allow us to evaluate the absolute and relative viability of many geologically reasonable but relatively simple thermal scenarios/options shown in Figure S3 (residence in the ZHe partial retention zone during the Cretaceous, inverse modeling simulation \#2; two-phase cooling, simulations \#1-3). Unknowns such as the prevailing vertical geothermal gradient and burial depth of the crustal block during rifting led us to vary the Early Cretaceous maximum temperature in each of the two model families.

Forward $t$ - $T$ paths were constrained with the same data as for inverse modeling:

(1) The initial time constraint in our forward models is placed at $305 \mathrm{Ma}$. As the Guenthner et al. (2013) model considers a partial annealing zone of $310-223^{\circ} \mathrm{C}$, placing any initial temperature constraint above this temperature range does not significantly affect the prediction results. Thus, the initial temperature constraint is placed at $600{ }^{\circ} \mathrm{C}$, regardless of the samples. As relatively little is known about cooling of the Agly-Salvezines rocks from Variscan times to the end Permian, samples are assumed to cool at a constant cooling rate from 305 to $250 \mathrm{Ma}$.

(2) Berger et al. (1993) indicate that the Saint-Arnac granite, and possibly the gneisses, may have been at or near the surface around Late Triassic times. Pressure estimates for albitization and Early Cretaceous mylonitisation in the massif (1.5-3 kbar; Pascal, 1979; work by R. Nicolas cited in Clerc et al., 2015) suggest that the lower part of the Saint-Arnac granite body was at around 4- to 5-km depth during the Early Cretaceous. The Bas-Agly and Saint-Paul-de-Fenouillet synclines record an Upper Triassic-to-lower Aptian sedimentary succession as thick as $\sim 1 \mathrm{~km}$. Assuming a vertical thermal gradient of $30{ }^{\circ} \mathrm{C} / \mathrm{km}$ during Triassic (post-Variscan orogeny relaxation), $t-T$ paths must reflect a temperature increase of $\sim 30{ }^{\circ} \mathrm{C}$ from $250 \mathrm{Ma}$ to $125 \mathrm{Ma}$. As the vertical repartition of our samples over post-Variscan times is largely unknown, we tested two end-members for sample depth from the end Permian to the early Aptian (see section 6.2.1.1).

(3) AHe and AFT data document a time-temperature history of our samples in the overall temperature range of $45-110{ }^{\circ} \mathrm{C}$. Two temperature constraints are therefore arbitrarily placed at 110 and $20^{\circ} \mathrm{C}$ at 45 and $40 \mathrm{Ma}$, respectively. Near-surface temperatures $\left(20^{\circ} \mathrm{C}\right)$ were then retained from this time until present.

Because all the samples present similar ranges of single-grain ZHe ages and age-eU correlations, irrespective of their rock type or location, we expect that they most likely experienced the same post-Early Cretaceous thermal history. To test this prediction, we generated for each $t-T$ path model an age-eU envelope that encompasses the 2-standard-deviation grain sizes measured as the equivalent spherical radius for the whole data set $(69 \pm 18 \mu \mathrm{m})$. These envelopes represent the range of age-eU curves that would be produced individually for a specific grain size in the 50 - to $87-\mu \mathrm{m}$ range. This aims to depict the age variation for a single sample resulting from the combined effects of radiation damage and grain size, that is, intrasample 
Initiation of early syn-orogenic cooling at $75 \mathrm{Ma}$
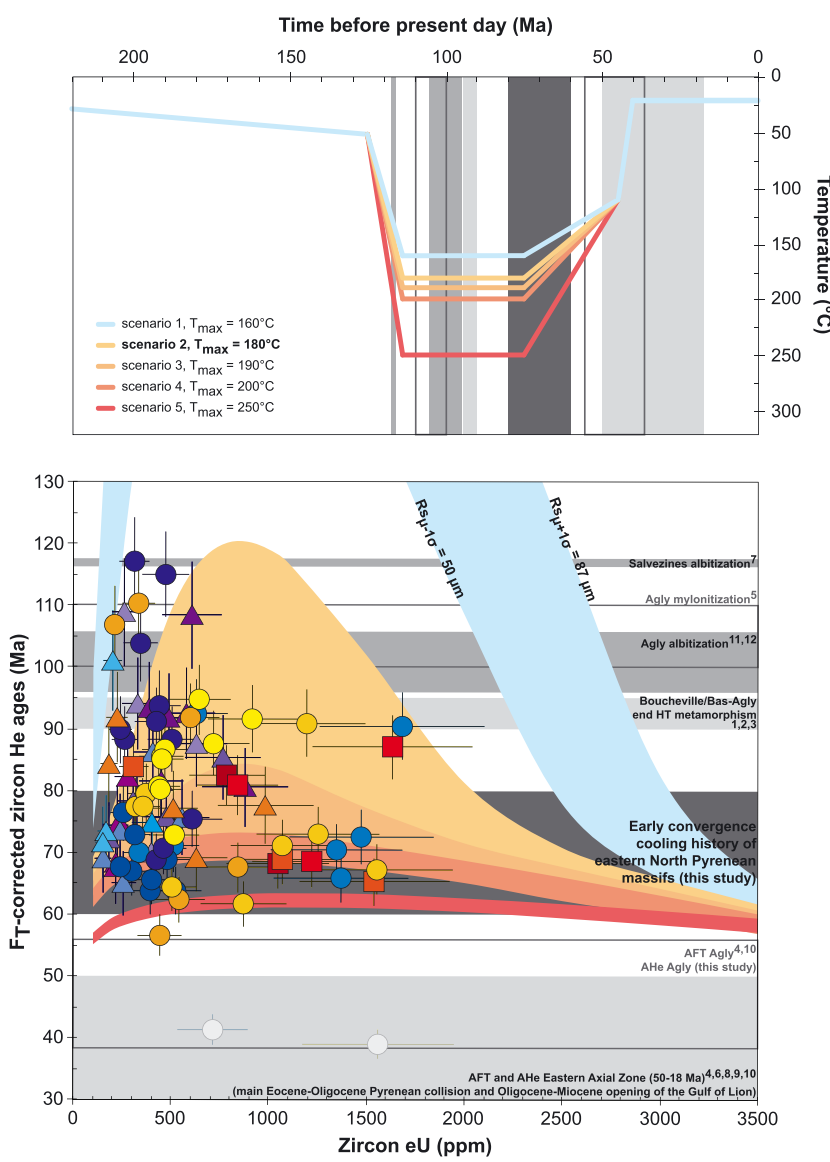

Initiation of early syn-orogenic cooling at $50 \mathrm{Ma}$
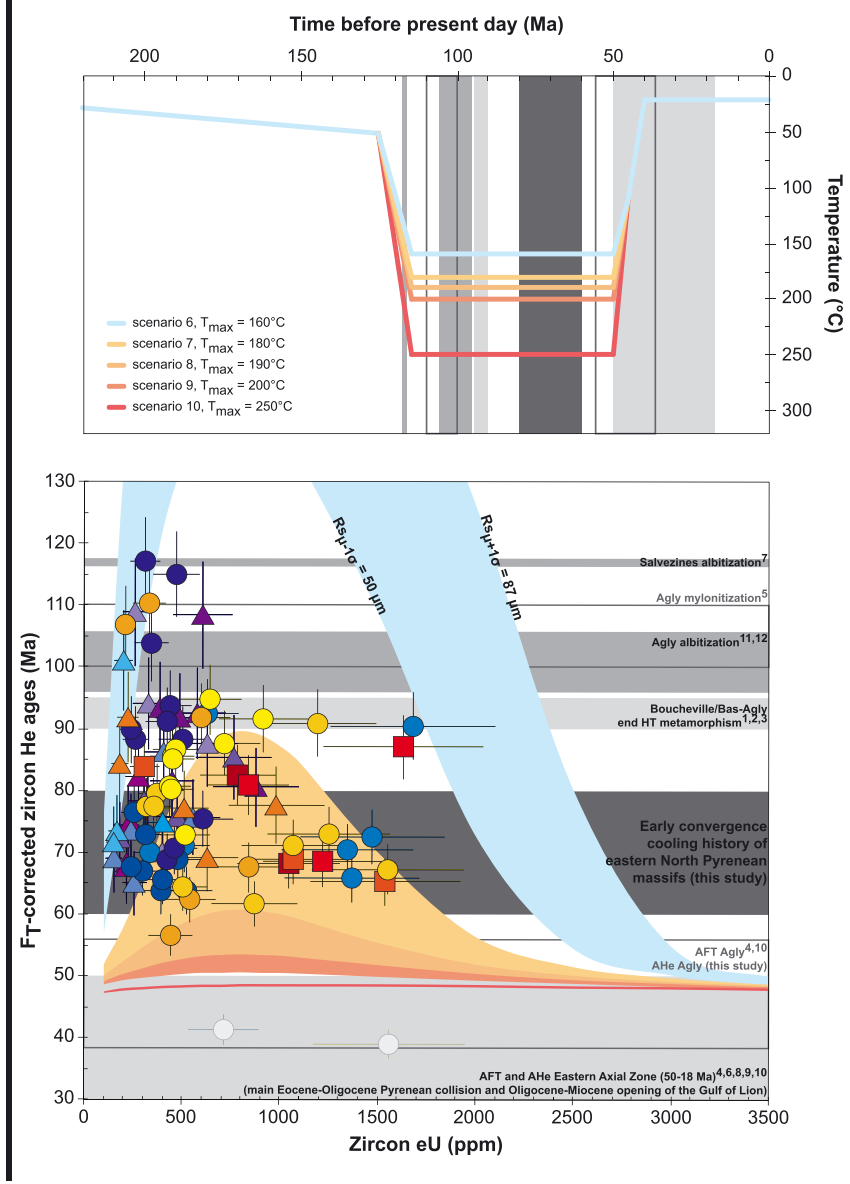

Figure 4. Comparison of the Agly-Salvezines age-eU data set with first family forward models assuming (i) shallow-crustal depths from the end Permian to the early Aptian followed by (ii) rapid heating during Early Cretaceous rifting. The top two panels show five different $t$ - $T$ scenarios with either (left) Late Cretaceous cooling at $75 \mathrm{Ma}$ or (right) Eocene cooling at $50 \mathrm{Ma}$. The resulting age-eU envelopes are plotted in the two bottom graphs with the color of each age-eU envelope matching a specific $t$ - $T$ path. Envelopes encompass the 2-standard-deviation grain sizes $(69 \pm 18 \mu \mathrm{m})$, so that the upper and lower bounds of the color envelopes correspond to the age-eU curve that would be produced for a grain size of 87 and $50 \mu \mathrm{m}$, respectively. Gray bars indicate the ages of major thermal and tectonic events from literature. See Figure 3 for references 1-12.

variation within our data set. The zonation effect, albeit not accurately characterized, could be here considered as part of the radiation damage effect for the reasons mentioned in section 5 .

Both groups of middle Cretaceous ZHe ages fall within error into the time span over which heating is expected to occur over the whole Pyrenean realm based on the following: (i) stratigraphically constrained rifting (114-97 Ma; Debroas, 1987, 1990), (ii) the HT-LP event recorded in the eastern Metamorphic Internal Zone (113-95 Ma; Albarède \& Michard-Vitrac, 1978; Golberg \& Leyreloup, 1990; Montigny et al., 1986), (iii) the widespread hydrothermal fluid circulation in North Pyrenean basement massifs (117$92 \mathrm{Ma}$; Boutin et al., 2016, and references therein), (iv) partial to total resetting of the ${ }^{40} \mathrm{Ar}^{-39} \mathrm{Ar}$ isotopic system in biotite and muscovite in mylonitic zones of the Agly basement (110-100 Ma; work by R. Nicolas cited in Clerc et al., 2015), and (v) mantle exhumation in the northwestern Pyrenees (108-105 Ma; Masini et al., 2014). On the other hand, temperatures inferred from the ZHe system in this study $\left(140-250{ }^{\circ} \mathrm{C}\right.$ and inverse modeling results) are far below (i) estimated RSCM temperatures in strata of Boucheville and Bas-Agly synforms (350-600 ${ }^{\circ} \mathrm{C}$; Chelalou, 2015; Chelalou et al., 2016; Ducoux, 2017; Vauchez et al., 2013) as well as in pockets of similar lithologies within the Agly Massif (400-450 ${ }^{\circ} \mathrm{C}$; Ducoux, 2017) and (ii) temperature conditions for albitization (350-450 ${ }^{\circ} \mathrm{C}$; Boulvais et al., 2007; Pascal, 1979; Poujol et al., 2010). Overall, either the middle Cretaceous ages may therefore be due to partial resetting of the (U-Th)/He system in zircon (heating up to the ZHe partial retention zone) or they may strictly date cooling that followed heating of the crustal 
Time before present day (Ma)
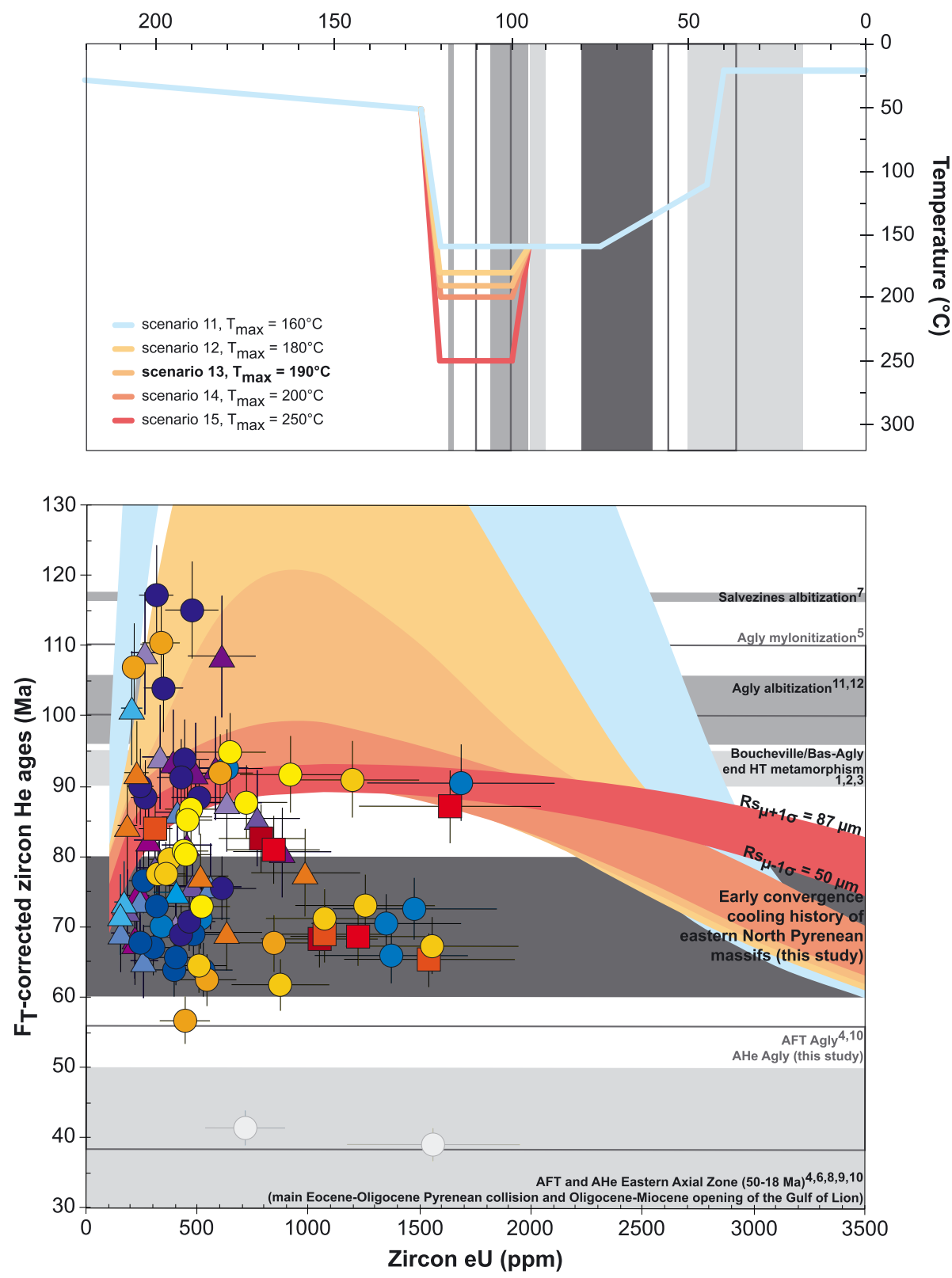

Figure 5. Second family $t$ - $T$ path forward model results for the Agly-Salvezines data set integrating two thermal cooling events. The top panel shows the five different $t-T$ scenarios tested, with Late Cretaceous cooling at $75 \mathrm{Ma}$ from structural levels at $160{ }^{\circ} \mathrm{C}$. The resulting age-eU envelopes are plotted in the bottom panel, with the color of each age-eU envelope matching a specific $t$ - $T$ path. Envelopes encompass the 2-standard-deviation grain sizes $(69 \pm 18 \mu \mathrm{m})$ so that the upper and lower bounds of the color envelopes correspond to the age-eU curve that would be produced for a grain size of 87 and $50 \mu \mathrm{m}$, respectively. Gray bars indicate the ages of major thermal and tectonic events from literature. See Figure 3 for references $1-12$.

block above the ZHe partial retention zone (total reset) during middle Cretaceous times. The significance of the sample groups' ZHe ages around the maximum of age-eU correlations therefore requires consideration and is investigated by testing a second family of slightly more complex $t$ - $T$ path models.

\subsubsection{First Family of $t$ - $T$ Path Models (Single-Phase Cooling History)}

The first family of $t$ - $T$ path models simulates five simple thermal histories (scenarios 1 to 10) based on the maximum temperature $\left(160,180,190,200\right.$, and $250{ }^{\circ} \mathrm{C}$ ) reached during rifting (at $115 \mathrm{Ma}$ in simulations) and the relative amount of cooling that occurred starting at either 75 or $50 \mathrm{Ma}$ (Figure 4). Thus, we test 
end-member scenarios with a phase of synorogenic cooling starting either in the Late Cretaceous (75 Ma, scenarios 1-5), implying rapid and full cooling of the Agly-Salvezines block during early orogenesis, or in the Eocene (50 Ma, scenarios 6-10), implying a long period of quiescence before orogenic cooling. Additionally, we present variants in Figures S5 and S6 that consider the following: (i) samples lay at 4- to 5-km depth before rifting and experienced temperatures of 120 to $150{ }^{\circ} \mathrm{C}$ (Figure S5) or (ii) maximum temperature is reached during rifting at $100 \mathrm{Ma}$ (Figure S6).

\subsubsection{Second Family of $\boldsymbol{t}$ - $\boldsymbol{T}$ Path Models (Two-Phase Cooling History)}

Four thermal histories with two distinct phases of cooling were tested (scenarios 11 to 15; Figure 5). These are variants of scenario 1 of the first family of $t$ - $T$ path models, with a cooling event from structural levels at $160{ }^{\circ} \mathrm{C}$ starting in the Late Cretaceous (75 Ma). An earlier phase of cooling is added in the middle Cretaceous (100 Ma) that follows a 20-myr period of relatively high temperatures since $120 \mathrm{Ma}$ (180, 190, 200, and $\left.250{ }^{\circ} \mathrm{C}\right)$.

\subsubsection{HeFTy Forward Modeling Results}

In the single-phase cooling models, samples of both groups lie within the ZHe partial retention zone from Early Cretaceous to Campanian times. The $t$ - $T$ paths models assuming a cooling phase starting at $75 \mathrm{Ma}$ appear to predict model age-eU curves that explain a high percentage of the observed ages over the whole spread in eU, while those assuming a cooling phase starting at $50 \mathrm{Ma}$ always predict ages at very low eU and very high eU that are far younger than almost all observed ZHe ages in the Agly-Salvezines data set. This is verified irrespective of the depth of our samples before the Early Cretaceous and the timing of end of heating before convergence (Figures 4, S5, and S6). In particular, scenario 2 is best able to reproduce the two groups' maximum cooling ages. The structural levels of $\mathrm{Gp} 1$ and $\mathrm{Gp} 2$ samples are not distinguishable over the period of modeling, although we might reasonably expect that the slightly different age clusters at low eU for Gp2 and Gp1 indicate that rocks lying at different vertical depths reached a particular closure temperature depth with some delay (section 5).

In the two-phase cooling models, samples of both groups lie within or deeper than the ZHe partial retention zone from mid-late Aptian to mid-late Cenomanian times ( 120-95 Ma in simulations). Most retentive zircon crystals (with higher closure temperatures) of both sample groups thus record cooling during this time (see age distributions in Figure $3 \mathrm{~b}$ ). One viable $t$ - $T$ path is found, producing the only age-eU envelope that encompasses a high percentage of the observed ZHe ages over the whole spread in eU (scenario 13; Figure 5). In this scenario, the structural levels of Gp1 and Gp2 samples are not clearly distinguishable over the time of modeling.

\section{Discussion}

\subsection{Interpretation of Data and Age-eU Correlations}

The age variability in our AHe data set and the higher AHe age values at high eU compared with those in published AFT data (Gunnell et al., 2009; Yelland, 1991) indicate fairly rapid cooling of our samples below temperatures of $110-45^{\circ} \mathrm{C}$ during early-middle Eocene (Ypresian-Lutetian) times. The overall positive AHe age-eU correlation illustrates the damage-dependent sensitivity of $\mathrm{He}$ in apatite to thermal processes as proposed and modeled by Flowers et al. (2007) and Gautheron et al. (2009). We interpret this cooling signature as due to denudation of the Agly-Salvezines block at the beginning of the main Eocene phase of orogenesis. Exhumation-related cooling is observed over the whole Pyrenees, propagating southward from the North Pyrenean basement massifs into the Axial Zone from the early Eocene to the late Oligocene (Bosch et al., 2016; Hart et al., 2017; Labaume et al., 2016; Mouthereau et al., 2014, and references therein; Rushlow et al., 2013; Thomson et al., 2017; Vacherat et al., 2014, 2016).

As with the AHe system, the clear age variation in our ZHe data set illustrates the damage-dependent sensitivity of He in zircon to thermal processes (Guenthner et al., 2013). Plotting single-grain ZHe ages against bulk eU clearly demonstrates the lack of a simple, straight correlation between age and radiation damage, which is likely due to grain size and zonation effects. Nonetheless, overall first-order positive and negative age-eU correlations seem to be displayed by ZHe ages as these increase from $\sim 75 \pm 5$ to $\sim 110 \pm 5 \mathrm{Ma}$ and then decrease down to $\sim 70 \pm 5$ Ma with increasing eU.

None of the predicted ZHe age-eU envelopes (Figures 4, 5, S5, and S6) explain all observed ages in the AglySalvezines data set. This result also clearly illustrates the difficulty in identifying a single $t$ - $T$ history using 
ZHe ages plotted against eU. As recently noted by some authors in other geologic settings (Anderson et al., 2017; Johnson et al., 2017; Powell et al., 2016; Vacherat et al., 2016), forward modeling suggests that the damage-dependent model of diffusion is able to reproduce only qualitatively, not quantitatively, the range of single-grain $\mathrm{ZHe}$ ages and both positive and negative age-eU correlations. This probably also explains the failure of the HeFTy software to produce plausible thermal histories when performing inverse modeling with too many input data.

Nevertheless, all our modeling results clearly concur with Guenthner et al. (2013), in that age-eU correlations yielded by a sample or a group of samples are the result of its entire history and are not only shaped by the most recent cooling event. They indicate to first order that the deeper the paleostructural level, the flater the predicted age-eU correlation and the younger the predicted maximum $\mathrm{ZHe}$ ages (scenarios 5 and 10, Figure 4; scenario 15, Figure 5). The most recent, rapid cooling history of a sample or a group of samples is dated at opposite ends of the eU concentration spectrum, irrespective of any earlier history. Any earlier thermal histories shape age-eU correlations for maximum predicted ages and constrain any positive and/or negative correlation trends for these older ages (referred to as the ZHe inheritance curve; Guenthner et al., 2015; Powell et al., 2016). This point is illustrated with some sensitivity tests in Figures S5 and S6 and will be discussed below.

The non-random distribution of the Agly-Salvezines single-grain ZHe ages, together with the closure temperature predictions of the Guenthner et al. (2013) model, allow us to suggest that the young ZHe ages $(75-70 \pm 5 \mathrm{Ma})$ at relatively low $(<600 \mathrm{ppm})$ and high $(>1,000 \mathrm{ppm})$ eU concentrations may correspond to zircon grains with He closure temperatures of 160 and $<140{ }^{\circ} \mathrm{C}$, respectively. Zircon grains that yield older, middle Cretaceous $\mathrm{ZHe}$ ages may have had higher closure temperatures ( $\mathrm{ca}$. $200-250^{\circ} \mathrm{C}$ ) due to higher $\mathrm{He}$ retentivity and required a longer residence time in the partial retention zone to be partially or totally reset.

\subsection{New Insights Into Retrowedge Thermal History}

Inverse and forward modeling of $t-T$ paths shows that ZHe ages of igneous and metamorphic rocks can be reproduced by assuming the same structural level and thus a common $t$ - $T$ history for the two groups from the Triassic onward. Gp1 and Gp2 samples belonged to either (1) a single and unique block from the Triassic onward while lying at the same depth or (2) two different blocks (northern granite block and southern granulite block) lying at the same depth that joined (necessarily before the Late Cretaceous) and cooled together thereafter. The geographical proximity of samples yielding middle Cretaceous cooling ages and the absence of conclusive field evidence for two separate blocks in Mesozoic times (Berger et al., 1993; Olivier et al., 2004, 2008) support the first option. This confirms our premodeling expectations and justifies the individualization of three representative age clusters for inverse modeling.

\subsubsection{Campanian-Maastrichtian Convergence-Related Cooling}

Based on closure temperature predictions of the Guenthner et al. (2013) model, we argue that similarity of mean ZHe ages for clusters at very low and high eU concentrations (75 and $70 \mathrm{Ma}$, respectively) shows near synchroneity in crossing multiple isotherms in the range $<140-160{ }^{\circ} \mathrm{C}$ from 70 to $75 \mathrm{Ma}$ (Figure $3 \mathrm{~b}$ ). This indicates a marked cooling event starting at $75 \mathrm{Ma}$. This is further supported by forward modeling, which indicates that the best fit of both positive and negative age-eU correlations to our data over the whole spread of eU values is obtained if we assume that the Agly-Salvezines crustal block was cooled from $75 \mathrm{Ma}$ (Figure 4).

This cooling event (below $120-160{ }^{\circ} \mathrm{C}$ ) postdates by some 10 myrs the onset of tectonic inversion (Choukroune, 1989; Muñoz, 1992), itself postdating by some 10 myrs the end of Aptian-Cenomanian rifting. Angrand et al. (2018) have shown that the major thermal pulse generated by Early Cretaceous rifting was not reequilibrated before the onset of convergence. Thermal cooling thus contributed to foreland basin subsidence, particularly in the central and, even more so, in the western Aquitaine Basin. Their results concur with Vacherat et al. $(2014,2016)$ who propose that in western parts of the North Pyrenean Zone, temperatures of $400-200^{\circ} \mathrm{C}$ (Clerc et al., 2015) persisted during the first 30-35 myrs of orogenesis due to an inherited thermal perturbation. As yet, no clear cooling event older than $50 \mathrm{Ma}$ has been documented in the western and central North Pyrenean basement massifs. In contrast, in the east the Agly-Salvezines crustal block had cooled to below $250{ }^{\circ} \mathrm{C}$ by the end of rifting (95-90 Ma) and clearly records a cooling event during early convergence. This difference in thermal histories along the orogen can be related to several causes. First, the rift may have been wider in the west (Tugend et al., 2014) than in the east, leading to a broader and 
more persistent thermal perturbation. Although higher in the eastern basins, the thermal perturbation was short-lived, cooling to $400-250^{\circ} \mathrm{C}$ (Spear, 1993) by 95-90 Ma (Albarède \& Michard-Vitrac, 1978; Golberg \& Maluski, 1988; Montigny et al., 1986). Second, assuming a constant convergence rate along the orogen, it would have taken longer to close the wider rift to the west, thus preserving the thermal perturbation for longer. A faster convergence rate in the east as documented recently by Macchiavelli et al. (2017) would further promote this trend.

Given this tectonic history, the cooling event at 75 Ma may have been caused by either postrift cooling or early Pyrenean orogenesis. From the end of rifting, thermal reequilibration causes a gradual cooling over, typically, 50 myrs (thermal time constant for a standard continental lithosphere; Allen \& Allen, 2013). It cannot therefore explain in an acceptable way a marked cooling event starting at $75 \mathrm{Ma}$, some 15-20 myrs after the end of rifting. We thus interpret the cooling signal as evidence for early orogenic inversion of the distal rifted margin. This agrees with Ford et al. (2016) and Grool et al. (2018) in identifying an early phase of distributed gentle inversion of rifted structures of the European plate (North Pyrenean Zone) due to thickskinned convergence during Campanian-Maastrichtian times.

In collisional settings an erosion-related exhumation of thickening crust is most commonly evoked as the principal cooling mechanism. However, early convergent margins are typically low relief and often submarine (e.g., Platt, 1986; Simpson, 2006). Based on foreland basin evolution, the early Pyrenean orogen also probably formed a low relief, possibly submarine edifice (Ford et al., 2016). This concurs with evidence of little or no erosion in the Axial Zone during this period (e.g., Fitzgerald et al., 1999). In such a setting, only continental underplating and/or thrusting can explain the rock cooling indicated by our data. These processes will be discussed further in a later section. Similar processes are invoked early in orogenesis for the active arc-continent collision of southern Taiwan (Mesalles et al., 2014).

\subsubsection{Preorogenic Thermal History of the Agly-Salvezines Area}

We investigated the whole post-Barremian thermal history using both inverse and forward modeling approaches. As inverse modeling results indicate partial to total reset of the ZHe system over the period of time considered, we attempted to decipher the significance of the middle Cretaceous ZHe ages by testing two families of $t$ - $T$ path forward models (section 6.2.1). One model from each family provides an acceptable fit for both positive and negative age-eU correlations of our data over the whole spread in eU (Figures 4 and 5): scenario 2 (single-phase history, $\operatorname{Tmax} 180{ }^{\circ} \mathrm{C}$ ) and scenario 13 (two-phase history, $\operatorname{Tmax} 190{ }^{\circ} \mathrm{C}$ ). Nonetheless, the two scenarios are so similar that the current calibration of the Guenthner et al. (2013) model does not allow us to differentiate between them. It is important to stress that here we have reached the model's limitations emanating from its parameterization requirements, as already detected by previous authors (Powell et al., 2016; Vacherat et al., 2016). We note that this model cannot simulate the older ages of our data set for any thermal history with maximum temperatures during rifting (120-95 Ma in simulations) higher than $190^{\circ} \mathrm{C}$ (e.g., scenarios 4, 5, 9, 10, 14, and 15). This observation is consistent with inverse modeling results for any shorter-lived heat pulse within this time window. This is of particular concern because the peak paleotemperatures constrained with the RSCM technique (Serre de Vergès; Figure 2) or the temperature estimates of albitization can reach $400-450{ }^{\circ} \mathrm{C}$ between 117 and 96 Ma (Boulvais et al., 2007; Demange et al., 1999; Ducoux, 2017; Poujol et al., 2010). Moreover, as highlighted in section 3.3.2, radiometric data from Mesozoic sediments indicate that the HT-LP event took place between 113 and 95 Ma, peaking at 95-90 Ma in the eastern Pyrenees. Whatever the heat source for HT conditions recorded in Mesozoic strata, it had to occur contemporaneously with local metasomatism in basement by middle Cenomanian (95 Ma). One might expect that peaking HT metamorphism on both sides of the AglySalvezines block would have heated the massif's edges. Middle Cretaceous ZHe ages obtained in this study are mainly yielded by samples from the southern block, directly north of the Boucheville syncline. These ages potentially record cooling below $250{ }^{\circ} \mathrm{C}$ during and after the HT/albitization event. This may therefore indicate that maximum temperatures inferred from the RSCM analysis were localized due to HT fluid circulation (Boulvais, 2016; Dauteuil \& Ricou, 1989) or were very short-lived (less than 20 myrs as indicated by inverse modeling). In both cases, they probably do not reflect background temperatures. This subsequently suggests that another cause has to be found to explain cooling in the middle Cretaceous in the two-phase cooling history (Figure 5), possibly rift-related exhumation. In the absence of medium-temperature thermochronology data it is not possible to further constrain the thermal histories of the northern and southern Agly compartments during the preorogenic stage. 
Although our $t-T$ path models do not have the necessary sensitivity and resolution to quantify cooling rates, they can reproduce data when involving temperatures higher than $160{ }^{\circ} \mathrm{C}$ during the overall heat perturbation (115-95 Ma in simulations). If the Agly-Salvezines block had seen a maximum vertical geothermal gradient of $80{ }^{\circ} \mathrm{C} / \mathrm{km}$ during the HT-LP event (113-95 Ma, peaking at 95-90 Ma) as proposed in Boucheville (Chelalou et al., 2016), it must have been buried below at least $2 \mathrm{~km}$ of Triassic-to-middle Cenomanian strata during the heating period. Our low-temperature thermochonology models therefore support the proposition of a continuous Albian-Cenomanian basin overlying the Agly basement (Clerc et al., 2015, 2016; Olivier, 2013). Our models also support middle Cretaceous exhumation that would be necessarily involved in the proposed, albeit extreme, unroofing of the Agly Massif by early Cenomanian times by some authors (Clerc \& Lagabrielle, 2014; Ravier, 1957; Vauchez et al., 2013).

\subsection{Crustal-Scale Model of Orogenic Tectonothermal Evolution for the Eastern Pyrenean Retrowedge}

We here combine our low-temperature thermochronology results with geological and geophysical data from literature to propose a model for the evolution of the eastern Pyrenean orogen and in particular the retrowedge from the Santonian to present day. This model is based on the sequential restoration of a crustal-scale N-S cross-section through the central Agly Massif (Figure 6) assuming constant crustal area and compressional pure shear. However, given the Oligocene-Miocene crustal thinning during the opening of the western Mediterranean (e.g., Faccenna et al., 2014; Gunnell et al., 2008), there is a high uncertainty associated with the assumption of constant crustal area. We use 32, 20, and $28 \mathrm{~km}$ for present-day Iberian, eastern North Pyrenean, and European crustal thicknesses, respectively (Chevrot et al., 2018; Diaz et al., 2018). Following Clerc et al. (2016) and inspired by modern analogs (Chenin et al., 2017; Reston, 2009; Sutra et al., 2013), we restore the eastern Pyrenees to a hyperextended rift in which the Agly-Salvezines block is surrounded by depocenters recording high temperatures (113-95 Ma) and with mantle exhumation below the more distal Boucheville basin. Key thermal events integrated into this model are that the Agly-Salvezines block (i) was affected by metasomatism from late Aptian to middle Cenomanian times followed by rapid cooling to $200-250{ }^{\circ} \mathrm{C}$ by $90 \mathrm{Ma}$ and (ii) was cooled at $75 \mathrm{Ma}$ during early convergence and again at $50 \mathrm{Ma}$ during main collision. Total retrowedge shortening on this cross section is estimated at $15 \mathrm{~km}$; total prowedge shortening is $31 \mathrm{~km}$ based on Laumonier et al. (2015). This model is consistent with recent numerical modeling studies (Dielforder et al., 2017).

\subsubsection{Preconvergence Phases (114-84 Ma): Early Cretaceous Crustal Template}

Figure 6a shows the preorogenic configuration (late Santonian). Using the work of Vergés et al. (1995) and Laumonier (2015), we propose a first-order restoration of the Iberian crust between the SPFT and the NPF to an 81-km-wide preorogenic margin with a narrow distal domain (33 km wide). A more detailed restoration of the European margin (from the NPF to the northern edge of the Mouthoumet Massif) is constrained by published geological maps and new field data and inspired by previous schematic reconstructions in that area (Figure 1; Choukroune, 1974; Chelalou et al., 2016; Clerc et al., 2016). The European margin is restored to a 66-km-wide rifted margin comprising an 11-km-wide proximal domain (Mouthoumet Massif), a 29-kmwide necking zone, a 17-km-wide zone of hyperthinned crust (the Agly-Salvezines block and Bas-Agly synform), and a 9-km-wide zone of exhumed mantle below the Boucheville depocenter. Major uncertainty is associated with the unknown amount of mantle exhumation. We therefore exclude closure of the exhumed mantle domain from all estimates of shortening given hereafter. The North Pyrenean Zone is restored to a 47-km-wide rifted margin, giving a minimum shortening of $\sim 12 \mathrm{~km}$. Following Grool et al. (2018) we assume that shortening in the retrowedge was accommodated equally between the two orogenic phases. The model shows major Aptian-Cenomanian rift depocenters controlled by basement faults at depth. Keuper evaporites and diapirs act as a decoupling layer between basement and cover. The crust is thinned to $0 \mathrm{~km}$ below the Boucheville depocenter and to $4 \mathrm{~km}$ below the Bas-Agly depocenter. The intervening Agly-Salvezines crustal block is thinned to $8 \mathrm{~km}$ (Clerc \& Lagabrielle, 2014; Clerc et al., 2015, 2016) and buried below at least $2 \mathrm{~km}$ of Mesozoic sediments (section 7.2.2).

7.3.2. First Orogenic Phase (84-66 Ma): Early Rift Inversion and Northward Underplating

During early convergence (Campanian-Maastrichtian; Figure $6 \mathrm{~b}$ ), a minimum of $\sim 17 \mathrm{~km}$ shortening is accommodated across the orogen. The mantle domain is closed, and the overlying Boucheville basin is transported northward and southward onto the continental margins. The Bac Grillera Superieure Thrust (or supra-axial thrust of Laumonier, 2015) is then activated to accommodate $\sim 5 \mathrm{~km}$ of thin-skinned 


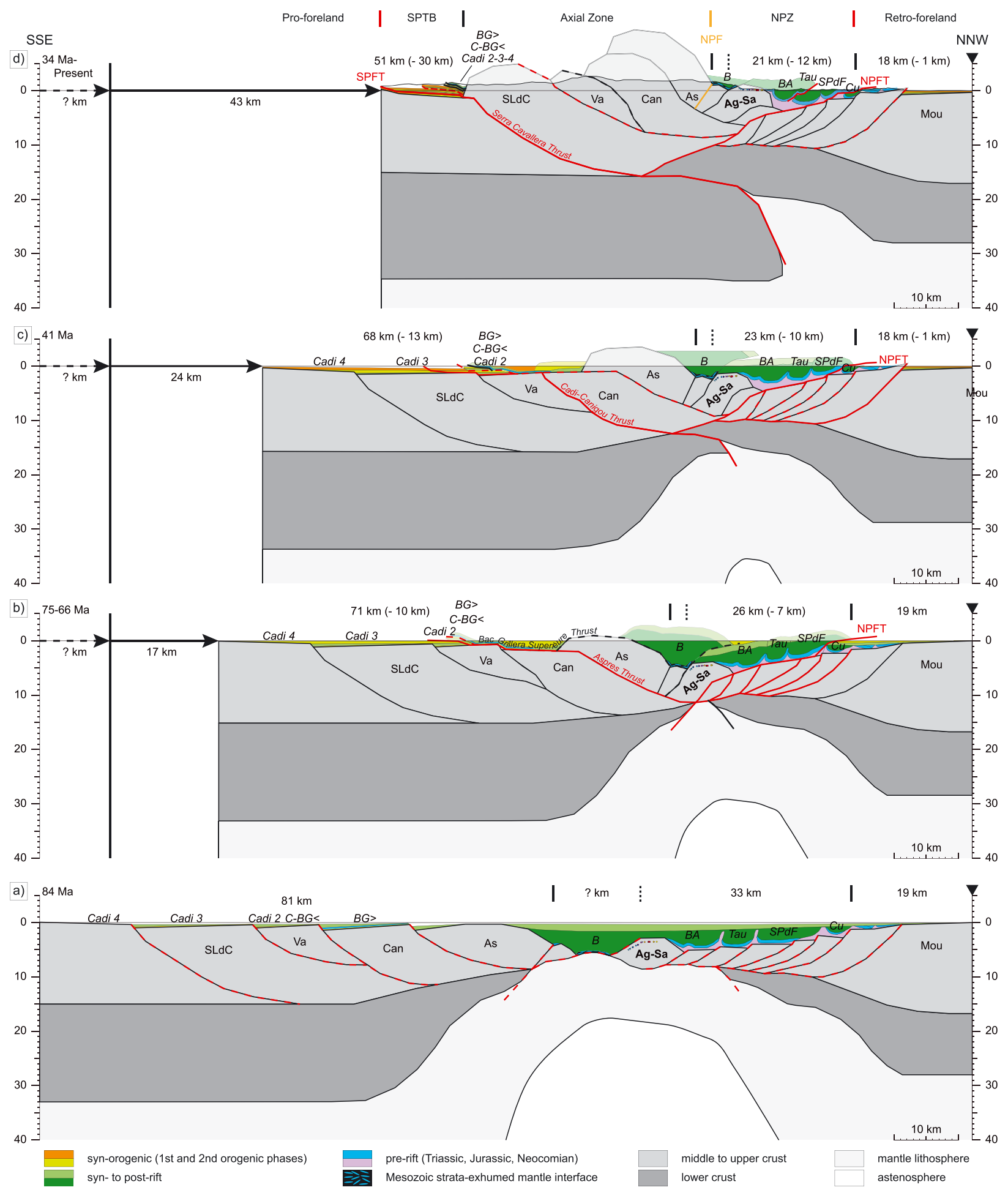

Figure 6. Sequentially balanced evolution of the eastern Pyrenees along a N-S section line located in Figures 1 and 2. Shortening amounts are cumulative. Solid red lines indicate faults that are active. Dashed red lines indicate faults that were active during the preceding step (those in black being abandoned before those in red). Black lines indicate abandoned faults. Approximate sample location is indicated on the Agly-Salvezines crustal block. The present-day Moho is that along the deep seismic tomography line E-E' passing though the Agly Massif of Chevrot et al. (2018) and Diaz et al. (2018; Figure 1). Width of the North Pyrenean Zone (NPZ) on the present-day cross section (Figure 6d) is larger than that on line $\mathrm{E}_{-} \mathrm{E}^{\prime}$ due to characteristics of the transect reconstructed in this study (Figures 1 and 2). SPTB $=$ South Pyrenean thrust belt; SPFT $=$ South Pyrenean Frontal Thrust; NPFT $=$ North Pyrenean Frontal Thrust; NPF $=$ North Pyrenean Fault; SLdC $=$ Saint Laurent-de-Cerdans; Va = Vallespir; Can = Canigou; As = Aspres; Ag-Sa = Agly-Salvezines; Mou = Mouthoumet; BG $>=$ Bac Grillera Superieure; C$\mathrm{BG}<=$ Coustouge-Bac Grillera Inferieure; B = Boucheville; BA = Bas-Agly; Tau = Tautavel; SPdF = Saint-Paul-de-Fenouillet; Cu = Cucugnan. 
shortening verging southward. It transports the Bac Grillera Superieure unit southward onto the CoustougeBac Grillera Inferieure unit. By middle Campanian times, the distal Iberian and European rifted crusts are in contact. The early orogenic edifice is a low-relief double wedge supplying little sediment into the early foreland basins. In this context, three structural scenarios could produce the cooling event recorded in the Agly-Salvezines crustal block: northward thrusting of the block onto the cooler proximal margin, northward underplating by the distal Iberian margin, or a combination of these two. The first two options would require amounts of shortening and structural geometries that are incompatible with present-day surface geology. The first scenario would require overthrusting of the entire Saint-Paul-de-Fenouillet synform by the Bas-Agly synform, while the second scenario would result in unrealistic mechanical deformation within the crust. In contrast, by combining more modest amounts of both overthrusting and underplating in the third option, we can reproduce present-day surface geometries. Faults across the distal margins are reactivated to accommodate $\sim 7$ and $\sim 5 \mathrm{~km}$ shortening in the northern retrowedge and southern prowedge, respectively. The NPFT and the Aspres Thrust become active at this time. The former links southward to the main crustal fault that carries the Agly-Salvezines block northward (similar to models of Ford et al., 2016; Rougier et al., 2016; and Grool et al., 2018). The latter carries the AglySalvezines block southward and further transports the Bac Grillera Superieure unit southward onto the Coustouge-Bac Grillera Inferieure unit.

\subsubsection{Retrowedge Quiescence Phase (66-59 Ma)}

During the Paleocene, convergence appears to stop (Grool et al., 2018; Macchiavelli et al., 2017). The absence of cooling indicates that the massif remains beneath $2-4 \mathrm{~km}$ of overburden, with no significant underplating-related or thrusting-related wedge thickening. Clastic supply from the orogen into the retroforeland basin is still minimal (Ford et al., 2016), indicating the absence of significant denudation of the orogen.

\subsubsection{Second Orogenic Phase (59-34 Ma): Main Collision and Prowedge Deformation}

In the early Eocene (Ypresian) the main continent-continent collision starts. By middle Eocene (Lutetian, $41 \mathrm{Ma}$; Figure 6c), continuing crustal thickening leads to emergence of the orogenic edifice and subaerial erosion. The Agly-Salvezines block is rapidly exhumed to near surface as the North Pyrenean Zone continues to shorten and deformation migrates northward. The NPFT is reactivated to accommodate $\sim 6-\mathrm{km}$ shortening, linking southward to the main crustal fault that carries the Agly-Salvezines block and the crustal imbricate it overthrusts. Thick-skinned shortening $(3 \mathrm{~km}$; only $1 \mathrm{~km}$ is shown in Figure 6 as $2 \mathrm{~km}$ is accommodated further north) affects the retroforeland, exploiting weak horizons in underlying Variscan nappes (e.g., uplift of the Mouthoumet Massif; Christophoul et al., 2003). Shortening is progressively transferred to the prowedge to the south (Axial Zone and southern foreland) with reactivation of the Aspres Thrust and activation of the Cadi-Canigou Thrust to accommodate a total $\sim 13-\mathrm{km}$ shortening. The Aspres Thrust accommodates much more shortening than it did during the first phase of orogenesis, transporting the Coustouge-Bac Grillera (Inferieure and Superieure) unit southward onto the Cadi 2 unit (Laumonier, 2015; Laumonier et al., 2015; Pujadas et al., 1989, and references therein). From the middle Eocene to the early Oligocene, exhumation rates for the Axial Zone increase (Bosch et al., 2016; Labaume et al., 2016; Mouthereau et al., 2014, and references therein; Rushlow et al., 2013; Whitchurch et al., 2011, and references therein) while the Agly exhumation ceased (Gunnell et al., 2009). The SPFT (or Vallfogona thrust in Laumonier, 2015) is activated to accommodate $\sim 7-\mathrm{km}$ shortening, linking northward to the Serra Cavallera Thrust (Laumonier, 2015). A total shortening of $\sim 26 \mathrm{~km}$ is therefore estimated during the second orogenic phase (Figure 6d).

\section{Conclusions}

We present new single-grain AHe and ZHe data for the North Pyrenean Agly-Salvezines block in the eastern Pyrenean retrowedge that provide new insight into collisional wedge growth. We use inverse modeling and forward modeling of these new results to better constrain the tectonic and thermal evolution of the distal European rifted margin during early convergence. By integrating our low-temperature data with published data, we propose a sequentially balanced crustal-scale model for the tectonic and thermal evolution of the eastern inverted rift through collision.

Applying both a dating technique to multiple grains from a single sample and multiple dating techniques to the same sample reduces uncertainties in investigating the time-temperature history of our samples within 
Acknowledgments

This work was funded by the OROGEN research project, Geological Society of America, American Association of Petroleum Geologists, Jackson School of Geosciences at the University of Texas (grants awarded to M. Odlum), and the UTChron Laboratory at the University of Texas. New lowtemperature thermochronology data are presented in the supporting information (Data Set S1). We thank two anonymous reviewers for their very constructive feedback and remarks that greatly helped clarify the manuscript. We thank Tectonics Editor T. Schildgen and Associate Editor J. Cottle for their comments and editorial support. We thank P. Olivier and B. Laumonier for invaluable assistance in the field, helpful insights, and intriguing discussions. We thank C. Gautheron, D. Marquer, P. Goncalves, P. Trap, M. de Saint Blanquat, F. Galster, K. Thomson, T. Capaldi, and current and former colleagues at the CRPG and the OROGEN team, in particular Emmanuel Masini and Thierry Baudin, for their help and fruitful discussions. Many thanks to A. Carter and S. Brichaud for providing us with raw AFT data for the Agly Massif. We would also like to thank P. Hild, D. Yeghicheyan (SARM, Nancy, France), and D. Patterson and L. Stockli for their assistance with data acquisition. CRPG publication number 2680 . the crust. We find that $\mathrm{ZHe}$ and AHe ages from the Agly-Salvezines block display correlations between age and eU. Using available radiation damage-He diffusivity models for apatite and zircon (Flowers et al., 2009; Guenthner et al., 2013), we interpret these correlations to be the result of grain-specific He diffusivities and closure temperatures. This allows us to investigate the thermal history of the crustal block in a larger and less discretized temperature range $\left(45-250{ }^{\circ} \mathrm{C}\right)$, and therefore over a longer period of time, than previously attempted.

In this study, we provide one of the largest bedrock ZHe data sets for the Pyrenean system. Zircon grains with the lowest closure temperatures $\left(<140-160{ }^{\circ} \mathrm{C}\right)$ represent half the grain population we analyzed for (U-Th)/He thermochronology. They yield the youngest ages (75-70 Ma), which are significantly older than the youngest ages obtained by the same dating technique in basement massifs further west, where the riftinherited thermal perturbation has been proved to be broad and persistent until the Eocene (Hart et al., 2017; Vacherat et al., 2014). We therefore interpret our Campanian-Maastrichtian bedrock ZHe ages to date a marked cooling event associated with early orogenic crustal thickening. Previously, the thermal signature of such an early phase of orogenesis has been only detected in synorogenic deposits from the central Pyrenees (Beamud et al., 2011; Filleaudeau et al., 2012; Mouthereau et al., 2014; Rahl et al., 2011; Thomson et al., 2017; Whitchurch et al., 2011). Cooling occurred while the early orogen was probably forming a low relief or even submarine edifice with little to no erosion (Ford et al., 2016). In this context and in the absence of additional data to further constrain early inversion mechanisms in the North Pyrenean Zone, we limit ourselves to a structural scenario that can explain Campanian-Maastrichtian rock cooling: a combination of northward thrusting of the Agly-Salvezines crustal block onto the cooler proximal margin and northward underplating by the distal Iberian margin. On the other hand, zircon grains with the highest closure temperatures $\left(200-250{ }^{\circ} \mathrm{C}\right.$ ) yield the oldest ages (117-90 Ma) for the Agly-Salvezines block. These ages are argued to record synrift to postrift cooling, suggesting that peak temperatures proposed in the literature for both the HT-LP metamorphic event and albitization/shear zone recrystallization most likely do not reflect the background temperatures that existed in the Agly-Salvezines crustal block during rifting. If these maximum temperatures existed, they would have been very short-lived (less than 20 myrs) and probably localized as hydrothermal activity in fault zones. Moreover, should a true cooling event have been recorded by the ZHe system in middle Cretaceous times (no partial reset), it would have been related to tectonic processes during Aptian-Cenomanian rifting. Medium-temperature thermochronology data are needed to further constrain the thermal histories of the Agly-Salvezines block during the preorogenic stage.

By showing the contemporaneity of crustal thermal events (cooling) with foreland tectonic events (subsidence) during convergence, this study provides new evidence for intimate coupling between the mountain belt and its foreland basin(s) even during earliest convergence. The insights gained into early orogenic wedge development also demonstrate the power that low-temperature thermochronology offers in detecting earliest crustal thickening.

\section{References}

Albarède, F., \& Michard-Vitrac, A. (1978). Age and significance of the North Pyrenean metamorphism. Earth and Planetary Science Letters, 40(3), 327-332. https://doi.org/10.1016/0012-821X(78)90157-7

Allen, P. A., \& Allen, J. R. (2013). Basin Analysis: Principles and application to petroleum play assessment (3rd ed.). West Sussex, UK: John Wiley \& Sons.

Althoff, F., Barbey, P., \& Pons, J. (1994). Hercynian age of an extensional tectonics in the Agly Massif (Pyrénées Orientales, France)— Evidence from the Ansignan charnockite and Saint-Arnac granite. Comptes Rendus de l'Académie des Sciences: Série 2, Mécanique, Physique, Chimie, Sciences de l'Univers, Sciences de la Terre, 319(2), 239-246.

Anderson, A. J., Hodges, K. V., \& van Soest, M. C. (2017). Empirical constraints on the effects of radiation damage on helium diffusion in zircon. Geochimica et Cosmochimica Acta, 218(Supplement C), 308-322. https://doi.org/10.1016/j.gca.2017.09.006

Andrieux, P. (1982). Crystallization conditions and evolution of an Hercynian charnockite-The Ansignan granulite complex (Agly Massif, French Pyrenees). Bulletin de Minéralogie, 105(3), 253-266.

Angrand, P., Ford, M., \& Watts, A. B. (2018). Lateral variations in foreland flexure of a rifted continental margin: The Aquitaine Basin (SW France). Tectonics, 37, 430-449. https://doi.org/10.1002/2017TC004670

Azambre, B., \& Ravier, J. (1978). Les écailles de gneiss du faciès granulite du Port de Saleix et de la région de Lherz (Ariege), nouveaux témoins du socle profond des Pyrénées. Bulletin de la Société Géologique de France, S7-XX(3), 221-228. https://doi.org/10.2113/gssgfbull. S7-XX.3.221

Baby, P., Crouzet, G., Specht, M., Déramond, J., Bilotte, M., \& Debroas, E.-J. (1988). Rôle des paléostructures albo-cénomaniennes dans la géométrie des chevauchements frontaux nord-pyrénéens. Comptes Rendus de l'Académie Des Sciences. Série 2, Mécanique, Physique, Chimie, Sciences de l'Univers, Sciences de La Terre, 306(4), 307-313. 
Barnolas, A., Chiron, J.-C., Guérangé, B., Autran, A., Durand-Delga, M., \& Fonboté, J. M. (Eds.) (1996). Synthèse Géologique et Géophysique Des Pyrénées. Introduction. Géophysique. Cycle Hercynien (Vol. 1). Orléans: BRGM.

Batt, G. E., Brandon, M. T., Farley, K. A., \& Roden-Tice, M. (2001). Tectonic synthesis of the Olympic Mountains segment of the Cascadia wedge, using two-dimensional thermal and kinematic modeling of thermochronological ages. Journal of Geophysical Research, 106(B11), 26,731-26,746. https://doi.org/10.1029/2001JB000288

Batt, G. E., \& Braun, J. (1997). On the thermomechanical evolution of compressional orogens. Geophysical Journal International, 128(2), 364-382. https://doi.org/10.1111/j.1365-246X.1997.tb01561.x

Batt, G. E., \& Braun, J. (1999). The tectonic evolution of the Southern Alps, New Zealand: Insights from fully thermally coupled dynamical modelling. Geophysical Journal International, 136(2), 403-420. https://doi.org/10.1046/j.1365-246X.1999.00730.x

Beamud, E., Muñoz, J. A., Fitzgerald, P. G., Baldwin, S. L., Garcés, M., Cabrera, L., \& Metcalf, J. R. (2011). Magnetostratigraphy and detrita apatite fission track thermochronology in syntectonic conglomerates: constraints on the exhumation of the south-central Pyrenees. Basin Research, 23(3), 309-331. https://doi.org/10.1111/j.1365-2117.2010.00492.x

Beaumont, C., Muñoz, J. A., Hamilton, J., \& Fullsack, P. (2000). Factors controlling the Alpine evolution of the central Pyrenees inferred from a comparison of observations and geodynamical models. Journal of Geophysical Research, 105(B4), 8121-8145. https://doi.org/ 10.1029/1999JB900390

Berger, G. M., Alabouvette, B., Bessière, G., Bilotte, M., Crochet, B., Dubar, M., et al. (1997). Notice explicative, Carte géol. France (1/50 000), feuille Tuchan (1078). Orléans: BRGM.

Berger, G. M., Bessière, G., Bilotte, M., \& Viallard, P. (1997). Carte géologique de France (1/50 000), feuille Tuchan (1078). Orléans: BRGM.

Berger, G. M., Fonteilles, M., Leblanc, D., Clauzon, G., Marchal, J. P., \& Vautrelle, C. (1993). Notice explicative, Carte géol. France (1/50 000), feuille Rivesaltes (1090). Orléans: BRGM

Bessière, G., Bilotte, M., Crochet, B., Peybernès, B., Tambareau, Y., \& Villatte, J. (1989). Notice explicative, Carte géol. France (1/50 000), feuille Quillan (1077). Orléans: BRGM.

Bilotte, M. (1985). Le Crétacé supérieur des plates-formes est-pyrénénnes (Vol. 5). Toulouse: Laboratoire de géologie sédimentaire et paléontologie, Université Paul Sabatier. Retrieved from https://strata.fr/libre-acces.html

Biteau, J.-J., Le Marrec, A., Le Vot, M., \& Masset, J.-M. (2006). The Aquitaine Basin. Petroleum Geoscience, 12(3), 247-273. https://doi.org/ 10.1144/1354-079305-674

Bosch, G., Teixell, A., Jolivet, M., Labaume, P., Stockli, D., Domènech, M., \& Monié, P. (2016). Timing of Eocene-Miocene thrust activity in the Western Axial Zone and Chaînons Béarnais (west-Central Pyrenees) revealed by multi-method thermochronology. Comptes Rendus Geoscience, 348(3-4), 246-256. https://doi.org/10.1016/j.crte.2016.01.001

Bouhallier, H., Choukroune, P., \& Ballèvre, M. (1991). Structural evolution of the deep Hercynian crust-The example of the Agly Massif (eastern Pyrenees, France). Comptes Rendus de l'Académie des Sciences. Série 2, Mécanique, Physique, Chimie, Sciences de l'Univers, Sciences de la Terre, 312(6), 647-654.

Boulvais, P. (2016). Fluid generation in the Boucheville Basin as a consequence of the North Pyrenean metamorphism. Comptes Rendus Geoscience, 348(3-4), 301-311. https://doi.org/10.1016/j.crte.2015.06.013

Boulvais, P., Ruffet, G., Cornichet, J., \& Mermet, M. (2007). Cretaceous albitization and dequartzification of Hercynian peraluminous granite in the Salvezines Massif (French Pyrénées). Lithos, 93(1-2), 89-106. https://doi.org/10.1016/j.lithos.2006.05.001

Boutin, A., de Saint Blanquat, M., Poujol, M., Boulvais, P., de Parseval, P., Rouleau, C., \& Robert, J.-F. (2016). Succession of Permian and Mesozoic metasomatic events in the eastern Pyrenees with emphasis on the Trimouns talc-chlorite deposit. International Journal of Earth Sciences, 105(3), 747-770. https://doi.org/10.1007/s00531-015-1223-x

Carrapa, B. (2010). Resolving tectonic problems by dating detrital minerals. Geology, 38(2), 191-192.

Chelalou, R. (2015). Formation et évolution du bassin de Boucheville, implication sur l'évolution tectonique, métamorphique et sédimentaire des bassins sédimentaires mésozoïques du Nord-Est des Pyrénées. Thèse de doctorat. Rennes: Université Rennes 1. Retrieved from http://www.theses.fr/2015REN1S164

Chelalou, R., Nalpas, T., Bousquet, R., Prevost, M., Lahfid, A., Poujol, M., et al. (2016). New sedimentological, structural and paleothermicity data in the Boucheville Basin (eastern North Pyrenean Zone, France). Comptes Rendus Geoscience, 348(3-4), 312-321. https:// doi.org/10.1016/j.crte.2015.11.008

Chenin, P., Manatschal, G., Picazo, S., Müntener, O., Karner, G., Johnson, C., \& Ulrich, M. (2017). Influence of the architecture of magmapoor hyperextended rifted margins on orogens produced by the closure of narrow versus wide oceans. Geosphere, 13(2), 559-576. https:// doi.org/10.1130/GES01363.1

Cherniak, D. J., Watson, E. B., \& Thomas, J. B. (2009). Diffusion of helium in zircon and apatite. Chemical Geology, 268(1-2), 155-166. https://doi.org/10.1016/j.chemgeo.2009.08.011

Chevrot, S., Sylvander, M., Diaz, J., Martin, R., Mouthereau, F., Manatschal, G., et al. (2018). The non-cylindrical crustal architecture of the Pyrenees. Scientific Reports, 8(1), 9591. https://doi.org/10.1038/s41598-018-27889-x

Choukroune, P. (1974). Structure et évolution tectonique de la zone nord-pyrénéenne: analyse de la déformation dans une portion de chaîne à schistosité sub-verticale. Thèse de doctorat. Montpellier: Université des Sciences et Techniques du Languedoc.

Choukroune, P. (1989). The Ecors Pyrenean deep seismic profile reflection data and the overall structure of an orogenic belt. Tectonics, 8(1), 23-39. https://doi.org/10.1029/TC008i001p00023

Christophoul, F., Soula, J.-C., Brusset, S., Elibana, B., Roddaz, M., Bessière, G., \& Déramond, J. (2003). Time, place and mode of propagation of foreland basin systems as recorded by the sedimentary fill: Examples of the Late Cretaceous and Eocene retro-foreland basins of the north-eastern Pyrenees. Special Publication-Geological Society of London, 208(1), 229-252. https://doi.org/10.1144/GSL. SP.2003.208.01.11

Clerc, C., \& Lagabrielle, Y. (2014). Thermal control on the modes of crustal thinning leading to mantle exhumation: Insights from the Cretaceous Pyrenean hot paleomargins. Tectonics, 33, 1340-1359. https://doi.org/10.1002/2013TC003471

Clerc, C., Lagabrielle, Y., Labaume, P., Ringenbach, J.-C., Vauchez, A., Nalpas, T., et al. (2016). Basement-cover decoupling and progressive exhumation of metamorphic sediments at hot rifted margin. Insights from the Northeastern Pyrenean analog. Tectonophysics, 686, 82-97. https://doi.org/10.1016/j.tecto.2016.07.022

Clerc, C., Lagabrielle, Y., Neumaier, M., Reynaud, J.-Y., \& de Saint Blanquat, M. (2012). Exhumation of subcontinental mantle rocks: Evidence from ultramafic-bearing clastic deposits nearby the Lherz peridotite body, French Pyrenees. Bulletin de la Société Géologique de France, 183(5), 443-459. https://doi.org/10.2113/gssgfbull.183.5.443

Clerc, C., Lahfid, A., Monié, P., Lagabrielle, Y., Chopin, C., Poujol, M., et al. (2015). High-temperature metamorphism during extreme thinning of the continental crust: A reappraisal of the North Pyrenean passive paleomargin. Solid Earth, 6(2), 643-668. https://doi.org/ $10.5194 / \mathrm{se}-6-643-2015$ 
Crochet, B., Villatte, J., Tambareau, Y., Bilotte, M., Bousquet, J. P., Kuhfuss, A., et al. (1989). Carte géologique de France (1/50 000), feuille Quillan (1077). Orléans: BRGM.

Crowley, P. D., Reiners, P. W., Reuter, J. M., \& Kaye, G. D. (2002). Laramide exhumation of the Bighorn Mountains, Wyoming: An apatite (U-Th)/He thermochronology study. Geology, 30(1), 27-30. https://doi.org/10.1130/0091-7613(2002)030<0027:LEOTBM>2.0.CO;2

Curnelle, R., Dubois, P., \& Seguin, J. C. (1980). Le bassin d'Aquitaine: Substratum anté-Tertiaire et bordures mésozoïques. In La Chaîne Des Pyrénées et Son Avant-Pays Aquitano-Languedocien, Bulletin Des Centres de Recherches Exploration-Production Elf-Aquitaine, Mémoire (Vol. 3, pp. 47-58).

Dauteuil, O., \& Ricou, L.-E. (1989). Hot-fluid circulation as an origin for the North Pyrenean cretaceous metamorphism. Geodinamica Acta, 3(3), 237-249. https://doi.org/10.1080/09853111.1989.11105190

Debroas, E.-J. (1987). Modèle de bassin triangulaire à l'intersection de décrochements divergents pour le fossé albo-cénomanien de la Ballongue (Zone Nord-Pyrénéenne, France). Bulletin de la Société Géologique de France, 8, 887-898.

Debroas, E.-J. (1990). Le Flysch noir albo-cénomanien témoin de la structuration albienne à sénonienne de la zone nord-pyrénéenne en Bigorre (Hautes-Pyrénées, France). Bulletin de la Société Géologique de France, 6(2), 283-285.

Delay, F. (1989). Le massif nord-pyrénéen de l'Agly (Pyrénées orientales): Évolution tectono-métamorphique et exemple d'un amincissement crustal polyphasé. Thèse de doctorat. Lille: Université Lille 1. Retrieved from http://www.theses.fr/1989LIL10175

Delay, F., \& Paquet, J. (1989). Tectonique ductile en extension dans le massif hercynien de l'Agly (Zone Nord-Pyrénéenne). Comptes Rendus de l'Académie des Sciences. Série 2, Mécanique, Physique, Chimie, Sciences de l'Univers, Sciences de la Terre, 308(18), 1637-1643.

Demange, M., Lia-Aragnouet, F., Pouliguen, M., Perrot, X., \& Sauvage, H. (1999). Les syénites du Castillet (massif de l'Agly, Pyrénées orientales, France): Une roche exceptionnelle dans les Pyrénées. Comptes Rendus de l'Académie des Sciences - Series IIA - Earth and Planetary Science, 329(5), 325-330. https://doi.org/10.1016/S1251-8050(00)88582-1

Demange, M., \& Pascal, M.-L. (1979). Structure du massif nord-pyrénéen de Salvezines (Aude). Comptes Rendus Académie Des Sciences de Paris, 289, 711-714.

Denèle, Y. (2007). Formation des dômes gneissiques hercyniens dans les Pyrénées: Exemple du massif de l'Aston-Hospitalet. Thèse de doctorat. Toulouse: Université Toulouse 3. Retrieved from http://www.theses.fr/2007TOU30274

Diaz, J., Vergés, J., Chevrot, S., Antonio-Vigil, A., Ruiz, M., Sylvander, M., \& Gallart, J. (2018). Mapping the crustal structure beneath the eastern Pyrenees. Tectonophysics, 744, 296-309. https://doi.org/10.1016/j.tecto.2018.07.011

Dielforder, A., Frasca, G., \& Ford, M. (2017). Initiation of the Pyrenean plate boundary fault and its effect on the near- and far-field deformation of the European plate (Vol. 19, p. 5144). Presented at the EGU General Assembly Conference Abstracts. Retrieved from http://adsabs.harvard.edu/abs/2017EGUGA..19.5144D

Dobson, K. J., Stuart, F. M., \& Dempster, T. J. (2008). U and Th zonation in Fish Canyon Tuff zircons: Implications for a zircon (U-Th)/He standard. Geochimica et Cosmochimica Acta, 72(19), 4745-4755.

Ducoux, M. (2017). Structure et évolution tectonique de la Zone Interne Métamorphique des Pyrénées. Thèse de doctorat. Orléans: Institut des Sciences de la Terre d'Orléans.

Faccenna, C., Becker, T. W., Auer, L., Billi, A., Boschi, L., Brun, J. P., et al. (2014). Mantle dynamics in the Mediterranean. Reviews of Geophysics, 52, 283-332. https://doi.org/10.1002/2013RG000444

Farley, K. A. (2000). Helium diffusion from apatite: General behavior as illustrated by Durango fluorapatite. Journal of Geophysical Research, 105(B2), 2903-2914. https://doi.org/10.1029/1999JB900348

Farley, K. A., Wolf, R. A., \& Silver, L. T. (1996). The effects of long alpha-stopping distances on (U-Th)/He ages. Geochimica et Cosmochimica Acta, 60(21), 4223-4229. https://doi.org/10.1016/S0016-7037(96)00193-7

Filleaudeau, P.-Y., Mouthereau, F., \& Pik, R. (2012). Thermo-tectonic evolution of the south-central Pyrenees from rifting to orogeny: Insights from detrital zircon $\mathrm{U} / \mathrm{Pb}$ and (U-Th)/He thermochronometry. Basin Research, 24(4), 401-417. https://doi.org/10.1111/j.13652117.2011.00535.x

Fillon, C., Huismans, R. S., \& van der Beek, P. (2013). Syntectonic sedimentation effects on the growth of fold-and-thrust belts. Geology, 41(1), 83-86. https://doi.org/10.1130/G33531.1

Fillon, C., \& van der Beek, P. (2012). Post-orogenic evolution of the southern Pyrenees: Constraints from inverse thermo-kinematic modelling of low-temperature thermochronology data. Basin Research, 24(4), 418-436. https://doi.org/10.1111/j.1365-2117.2011.00533.x

Fitzgerald, P. G., Muñoz, J. A., Coney, P. J., \& Baldwin, S. L. (1999). Asymmetric exhumation across the Pyrenean orogen: Implications for the tectonic evolution of a collisional orogen. Earth and Planetary Science Letters, 173(3), 157-170. https://doi.org/10.1016/S0012$821 \mathrm{X}(99) 00225-3$

Flowers, R. M., Farley, K. A., \& Ketcham, R. A. (2015). A reporting protocol for thermochronologic modeling illustrated with data from the Grand Canyon. Earth and Planetary Science Letters, 432, 425-435. https://doi.org/10.1016/j.epsl.2015.09.053

Flowers, R. M., Ketcham, R. A., Shuster, D. L., \& Farley, K. A. (2009). Apatite (U-Th)/He thermochronometry using a radiation damage accumulation and annealing model. Geochimica et Cosmochimica Acta, 73(8), 2347-2365. https://doi.org/10.1016/j.gca.2009.01.015

Flowers, R. M., Shuster, D. L., Wernicke, B. P., \& Farley, K. A. (2007). Radiation damage control on apatite (U-Th)/He dates from the Grand Canyon region, Colorado Plateau. Geology, 35(5), 447-450. https://doi.org/10.1130/G23471A.1

Fonteilles, M., Leblanc, D., Clauzon, G., Vaudin, J. L., \& Berger, G. M. (1993). Carte géologique de France (1/50 000), feuille Rivesaltes (1090). Orléans: BRGM.

Ford, M., Hemmer, L., Vacherat, A., Gallagher, K., \& Christophoul, F. (2016). Retro-wedge foreland basin evolution along the ECORS line, eastern Pyrenees, France. Journal of the Geological Society, 173(3), 419-437. https://doi.org/10.1144/jgs2015-129

Gallagher, K., Brown, R., \& Johnson, C. (1998). Fission track analysis and its applications to geological problems. Annual Review of Earth and Planetary Sciences, 26(1), 519-572. https://doi.org/10.1146/annurev.earth.26.1.519

Gautheron, C., Tassan-Got, L., Barbarand, J., \& Pagel, M. (2009). Effect of alpha-damage annealing on apatite (U-Th)/He thermochronology. Chemical Geology, 266(3-4), 157-170. https://doi.org/10.1016/j.chemgeo.2009.06.001

Godard, V., Pik, R., Lavé, J., Cattin, R., Tibari, B., de Sigoyer, J., et al. (2009). Late Cenozoic evolution of the central Longmen Shan, eastern Tibet: Insight from (U-Th)/He thermochronometry. Tectonics, 28, TC5009. https://doi.org/10.1029/2008TC002407

Golberg, J.-M., \& Leyreloup, A. F. (1990). High temperature-low pressure Cretaceous metamorphism related to crustal thinning (Eastern North Pyrenean Zone, France). Contributions to Mineralogy and Petrology, 104(2), 194-207. https://doi.org/10.1007/BF00306443

Golberg, J.-M., \& Maluski, H. (1988). Données nouvelles et mise au point sur l'âge du métamorphisme pyrénéen. Comptes Rendus de l'Académie Des Sciences. Série 2, Mécanique, Physique, Chimie, Sciences de l'Univers, Sciences de La Terre, 306(6), 429-435.

Grool, A. R., Ford, M., Vergés, J., Huismans, R. S., Christophoul, F., \& Dielforder, A. (2018). Insights into the crustal-scale dynamics of a doubly vergent orogen from a quantitative analysis of its forelands: A case study of the eastern Pyrenees. Tectonics, 37, 450-476. https:// doi.org/10.1002/2017TC004731 
Guenthner, W. R., Reiners, P. W., DeCelles, P. G., \& Kendall, J. (2015). Sevier belt exhumation in central Utah constrained from complex zircon (U-Th)/He data sets: Radiation damage and He inheritance effects on partially reset detrital zircons. Geological Society of America Bulletin, 127(3-4), 323-348. https://doi.org/10.1130/B31032.1

Guenthner, W. R., Reiners, P. W., Drake, H., \& Tillberg, M. (2017). Zircon, titanite, and apatite (U-Th)/He ages and age-eU correlations from the Fennoscandian Shield, southern Sweden: Fennoscandian Zirc He age-eU correlation. Tectonics, 36, 1254-1274. https://doi.org/ 10.1002/2017TC004525

Guenthner, W. R., Reiners, P. W., Ketcham, R. A., Nasdala, L., \& Giester, G. (2013). Helium diffusion in natural zircon: Radiation damage, anisotropy, and the interpretation of zircon (U-Th)/He thermochronology. American Journal of Science, 313(3), 145-198. https://doi.org/ 10.2475/03.2013.01

Guenthner, W. R., Reiners, P. W., \& Tian, Y. (2014). Interpreting date-eU correlations in zircon (U-Th)/He datasets: A case study from the Longmen Shan, China. Earth and Planetary Science Letters, 403, 328-339. https://doi.org/10.1016/j.epsl.2014.06.050

Guinault, M., Hallot, E., Boulvais, P., Poujol, M., de Saint Blanquat, M., \& Rémy, P. (2016). L'albitisation dans le granite de Lansac-St Arnac: paroxysme de la métasomatose sodique pyrénéenne au Crétacé. In 25ème Réunion des sciences de la Terre (RST 2016) (p. 152).

Gunnell, Y., Calvet, M., Brichau, S., Carter, A., Aguilar, J.-P., \& Zeyen, H. (2009). Low long-term erosion rates in high-energy mountain belts: Insights from thermo- and biochronology in the eastern Pyrenees. Earth and Planetary Science Letters, 278(3-4), 208-218. https:// doi.org/10.1016/j.epsl.2008.12.004

Gunnell, Y., Zeyen, H., \& Calvet, M. (2008). Geophysical evidence of a missing lithospheric root beneath the eastern Pyrenees: Consequences for post-orogenic uplift and associated geomorphic signatures. Earth and Planetary Science Letters, 276(3-4), 302-313. https://doi.org/10.1016/j.epsl.2008.09.031

Hart, N. R., Stockli, D. F., Lavier, L. L., \& Hayman, N. W. (2017). Thermal evolution of a hyperextended rift basin, Mauléon Basin, western Pyrenees. Tectonics, 36, 1103-1128. https://doi.org/10.1002/2016TC004365

Hourigan, J. K., Reiners, P. W., \& Brandon, M. T. (2005). U-Th zonation-dependent alpha-ejection in (U-Th)/He chronometry. Geochimica et Cosmochimica Acta, 69(13), 3349-3365. https://doi.org/10.1016/j.gca.2005.01.024

Jammes, S., Manatschal, G., Lavier, L., \& Masini, E. (2009). Tectonosedimentary evolution related to extreme crustal thinning ahead of a propagating ocean: Example of the western Pyrenees. Tectonics, 28, TC4012. https://doi.org/10.1029/2008TC002406

Johnson, J. E., Flowers, R. M., Baird, G. B., \& Mahan, K. H. (2017). "Inverted” zircon and apatite (U-Th)/He dates from the Front Range, Colorado: High-damage zircon as a low-temperature $\left(<50^{\circ} \mathrm{C}\right)$ thermochronometer. Earth and Planetary Science Letters, 466(supplement C), 80-90. https://doi.org/10.1016/j.epsl.2017.03.002

Ketcham, R. A. (2005). Forward and inverse modeling of low-temperature thermochronometry data. Reviews in Mineralogy and Geochemistry, 58(1), 275-314. https://doi.org/10.2138/rmg.2005.58.11

Ketcham, R. A., Gautheron, C., \& Tassan-Got, L. (2011). Accounting for long alpha-particle stopping distances in (U-Th-Sm)/He geochronology: Refinement of the baseline case. Geochimica et Cosmochimica Acta, 75(24), 7779-7791. https://doi.org/10.1016/j.gca.2011.10.011

Ketcham, R. A., Guenthner, W. R., \& Reiners, P. W. (2013). Geometric analysis of radiation damage connectivity in zircon, and its implications for helium diffusion. American Mineralogist, 98(2-3), 350-360. https://doi.org/10.2138/am.2013.4249

Labaume, P., Meresse, F., Jolivet, M., \& Teixell, A. (2016). Exhumation sequence of the basement thrust units in the west-central Pyrenees. Constraints from apatite fission track analysis. Geogaceta, 60, 11-14.

Lagabrielle, Y., \& Bodinier, J.-L. (2008). Submarine reworking of exhumed subcontinental mantle rocks: Field evidence from the Lherz peridotites, French Pyrenees. Terra Nova, 20(1), 11-21. https://doi.org/10.1111/j.1365-3121.2007.00781.x

Lagabrielle, Y., Labaume, P., \& de Saint Blanquat, M. (2010). Mantle exhumation, crustal denudation, and gravity tectonics during Cretaceous rifting in the Pyrenean realm (SW Europe): Insights from the geological setting of the lherzolite bodies: Pyrenean lherzolites, gravity tectonics. Tectonics, 29, TC4012. https://doi.org/10.1029/2009TC002588

Laumonier, B. (2015). Les Pyrénées alpines sud-orientales (France, Espagne) - essai de synthèse. Revue de Géologie Pyrénéenne, 2(1). Retrieved from http://www.geologie-des-pyrenees.com/wp-content/uploads/2015/10/Laumonier-2015-Pyr\%C3\%A9n\%C3\%A9esalpines-sud-orientales.pdf

Laumonier, B., Calvet, M., Wiazemsky, M., Barbey, P., Marignac, C., Lambert, J., \& Lenoble, J.-L. (2015). Notice explicative, Carte géol. France (1/50 000), feuille Céret (1096). Orléans: BRGM.

Macchiavelli, C., Vergés, J., Schettino, A., Fernàndez, M., Turco, E., Casciello, E., et al. (2017). A new southern North Atlantic isochron map: Insights into the drift of the Iberian Plate since the Late Cretaceous. Journal of Geophysical Research: Solid Earth, 122, 9603-9626. https://doi.org/10.1002/2017JB014769

Masini, E., Manatschal, G., Tugend, J., Mohn, G., \& Flament, J. M. (2014). The tectono-sedimentary evolution of a hyper-extended rift basin: The example of the Arzacq-Mauléon rift system (western Pyrenees, SW France). International Journal of Earth Sciences, 103(6), 1569-1596. https://doi.org/10.1007/s00531-014-1023-8

Maurel, O. (2003). L'exhumation de la Zone Axiale des Pyrénées orientales: Une approche thermo-chronologique multi-méthodes du rôle des failles. Thèse de doctorat. Montpellier: Université Montpellier II-Sciences et Techniques du Languedoc.

Maurel, O., Monié, P., Pik, R., Arnaud, N., Brunel, M., \& Jolivet, M. (2008). The Meso-Cenozoic thermo-tectonic evolution of the eastern Pyrenees: $\mathrm{An}{ }^{40} \mathrm{Ar} /{ }^{39} \mathrm{Ar}$ fission track and (U-Th)/He thermochronological study of the Canigou and Mont-Louis massifs. International Journal of Earth Sciences, 97(3), 565-584. https://doi.org/10.1007/s00531-007-0179-X

Mesalles, L., Mouthereau, F., Bernet, M., Chang, C.-P., Lin, A. T.-S., Fillon, C., \& Sengelen, X. (2014). From submarine continental accretion to arc-continent orogenic evolution: The thermal record in southern Taiwan. Geology, 42(10), 907-910. https://doi.org/ $10.1130 / \mathrm{G} 35854.1$

Monod, B. (2014). Carte géologique numérique à 1/250 000 de la région Midi-Pyrénées. Notice technique. BRGM/RP-63650-FR, 160p., 23fig., 1pl. hors-texte. Orléans, France.

Montigny, R., Azambre, B., Rossy, M., \& Thuizat, R. (1986). The geological evolution of the Pyrenees K-Ar study of Cretaceous magmatism and metamorphism in the Pyrenees: Age and length of rotation of the Iberian Peninsula. Tectonophysics, 129(1-4), 257-273. https://doi. org/10.1016/0040-1951(86)90255-6

Mouthereau, F., Filleaudeau, P.-Y., Vacherat, A., Pik, R., Lacombe, O., Fellin, M. G., et al. (2014). Placing limits to shortening evolution in the Pyrenees: Role of margin architecture and implications for the Iberia/Europe convergence: Plate convergence in the Pyrenees. Tectonics, 33, 2283-2314. https://doi.org/10.1002/2014TC003663

Muñoz, J. A. (1992). Evolution of a continental collision belt: ECORS-Pyrenees crustal balanced cross-section. In Thrust tectonics (pp. 235-246). Dordrecht, Netherlands: Springer.

Naylor, M., \& Sinclair, H. D. (2008). Pro- vs. retro-foreland basins. Basin Research, 20(3), 285-303. https://doi.org/10.1111/j.13652117.2008.00366.x 
Odlum, M., \& Stockli, D. F. (2017). Thermotectonic evolution of the North Pyrenean Agly Massif from hyperextension through inversion using multi-mineral thermochronometry (Vol. 19, p. 11277). Presented at the EGU General Assembly Conference abstracts.

Olivier, P. (2013). Comment on "Preorogenic exhumation of the North Pyrenean Agly Massif (eastern Pyrenees-France)" by A. Vauchez et al. Tectonics, 32, 821-822. https://doi.org/10.1002/tect.20049

Olivier, P., Gleizes, G., Paquette, J.-L., \& Muñoz Sáez, C. (2008). Structure and U-Pb dating of the Saint-Arnac pluton and the Ansignan charnockite (Agly Massif): A cross-section from the upper to the middle crust of the Variscan eastern Pyrenees. Journal of the Geological Society, 165(1), 141-152. https://doi.org/10.1144/0016-76492006-185

Olivier, P., Gleizes, G., \& Paquette, J. L. (2004). Gneiss domes and granite emplacement in an obliquely convergent regime: New interpretation of the Variscan Agly Massif (eastern Pyrenees, France). In D. L. Whitney, C. Teyssier, \& C. S. Siddoway (Eds.), Gneiss Domes in Orogeny (Vol. 380, pp. 229-242). Boulder, CO: Geological Soc Amer Inc. https://doi.org/10.1130/0-8137-2380-9.229

Paquet, J., \& Delay, F. (1989). Electron-microscope study of North Pyrenean mylonites (St Barthelemy and Agly Massifs, France) and discussion of their ages. Bulletin de la Société Géologique de France, 5(6), 1111-1122.

Paquet, J., \& Mansy, J.-L. (1992). Alpine evolution of the North-Pyrenean Agly Massif (eastern Pyrenees). Comptes Rendus de l'Académie des Sciences. Série 2, Mécanique, Physique, Chimie, Sciences de l'Univers, Sciences de la Terre, 315(4), 487-494.

Paquet, J., \& Mansy, J.-L. (1991). La structure de l'Est des Pyrénées (transversales du massif de l'Agly) : un exemple d'amincissement crustal Comptes Rendus de l'Académie des Sciences. Série 2, Mécanique, Physique, Chimie, Sciences de l'Univers, Sciences de la Terre, 312(8), 913-919.

Pascal, M.-L. (1979). Les albitites du Massif de l'Agly (Pyrénées-Orientales). Thèse de doctorat. Paris: ENSMP.

Peyton, S. L., \& Carrapa, B. (2013). An introduction to low-temperature thermochronologic techniques, methodology, and applications. In C. Knight \& J. Cuzella (Eds.), Application of structural methods to Rocky Mountain hydrocarbon exploration and development: AAPG Studies in Geology 65 (pp. 15-36).

Pik, R., Marty, B., Carignan, J., \& Lavé, J. (2003). Stability of the Upper Nile drainage network (Ethiopia) deduced from (U-Th)/He thermochronometry: Implications for uplift and erosion of the Afar plume dome. Earth and Planetary Science Letters, 215(1-2), 73-88. https://doi.org/10.1016/S0012-821X(03)00457-6

Platt, J. P. (1986). Dynamics of orogenic wedges and the uplift of high-pressure metamorphic rocks. Geological Society of America Bulletin, 97(9), 1037-1053. https://doi.org/10.1130/0016-7606(1986)97<1037:DOOWAT>2.0.CO;2

Plaziat, J.-C. (1981). Late Cretaceous to late Eocene palaeogeographic evolution of southwest Europe. Palaeogeography, Palaeoclimatology, Palaeoecology, 36(3-4), 263-320. https://doi.org/10.1016/0031-0182(81)90110-3

Poujol, M., Boulvais, P., \& Kosler, J. (2010). Regional-scale Cretaceous albitization in the Pyrenees: Evidence from in situ U-Th-Pb dating of monazite, titanite and zircon. Journal of the Geological Society, 167(4), 751-767. https://doi.org/10.1144/0016-76492009-144

Powell, J., Schneider, D., Stockli, D., \& Fallas, K. (2016). Zircon (U-Th)/He thermochronology of Neoproterozoic strata from the Mackenzie Mountains, Canada: Implications for the Phanerozoic exhumation and deformation history of the northern Canadian Cordillera. Tectonics, 35, 663-689. https://doi.org/10.1002/2015TC003989

Prior, M. G., Stockli, D. F., \& Singleton, J. S. (2016). Miocene slip history of the Eagle Eye detachment fault, Harquahala Mountains metamorphic core complex, west-central Arizona. Tectonics, 35, 1913-1934. https://doi.org/10.1002/2016TC004241

Pujadas, J., Casas, J. M., Muñoz, J. A., \& Sabat, F. (1989). Thrust tectonics and paleogene syntectonic sedimentation in the Empordà area, southeastern Pyrenees. Geodinamica Acta, 3(3), 195-206. https://doi.org/10.1080/09853111.1989.11105186

Rahl, J. M., Haines, S. H., \& van der Pluijm, B. A. (2011). Links between orogenic wedge deformation and erosional exhumation: Evidence from illite age analysis of fault rock and detrital thermochronology of syn-tectonic conglomerates in the Spanish Pyrenees. Earth and Planetary Science Letters, 307(1-2), 180-190. https://doi.org/10.1016/j.epsl.2011.04.036

Ravier, J. (1957). Le métamorphisme des terrains secondaires des Pyrénées. Dans: Mém. Soc. Géol. de France, NS, T. 38 (Mém. N 86). Thèse de doctorat.

Ravier, J., \& Thiébaut, J. (1982). Sur l'origine lagunaire des marbres et cornéennes mésozoïques du col d'Agnès (Ariège). Comptes Rendus Académie des Sciences, 294, 127-130.

Reiners, P. W., Farley, K. A., \& Hickes, H. J. (2002). He diffusion and (U-Th)/He thermochronometry of zircon: Initial results from Fish Canyon Tuff and Gold Butte. Tectonophysics, 349(1-4), 297-308. https://doi.org/10.1016/S0040-1951(02)00058-6

Reiners, P. W., Spell, T. L., Nicolescu, S., \& Zanetti, K. A. (2004). Zircon (U-Th)/He thermochronometry: He diffusion and comparisons with ${ }^{40} \mathrm{Ar} /{ }^{39} \mathrm{Ar}$ dating. Geochimica et Cosmochimica Acta, 68(8), 1857-1887. https://doi.org/10.1016/j.gca.2003.10.021

Reston, T. J. (2009). The structure, evolution and symmetry of the magma-poor rifted margins of the North and Central Atlantic: A synthesis. Tectonophysics, 468(1-4), 6-27. https://doi.org/10.1016/j.tecto.2008.09.002

Rougier, G., Ford, M., Christophoul, F., \& Bader, A.-G. (2016). Stratigraphic and tectonic studies in the central Aquitaine Basin, northern Pyrenees: Constraints on the subsidence and deformation history of a retro-foreland basin. Comptes Rendus Geoscience, 348(3-4), 224-235. https://doi.org/10.1016/j.crte.2015.12.005

Roure, F., Choukroune, P., Berastegui, X., Muñoz, J. A., Villien, A., Matheron, P., et al. (1989). ECORS deep seismic data and balanced cross sections: Geometric constraints on the evolution of the Pyrenees. Tectonics, 8(1), 41-50. https://doi.org/10.1029/ TC008i001p00041

Rushlow, C. R., Barnes, J. B., Ehlers, T. A., \& Vergés, J. (2013). Exhumation of the southern Pyrenean fold-thrust belt (Spain) from orogenic growth to decay. Tectonics, 32, 843-860. https://doi.org/10.1002/tect.20030

Séranne, M. (1999). The Gulf of Lion continental margin (NW Mediterranean) revisited by IBS: An overview. Geological Society, London, Special Publications, 156(1), 15-36. https://doi.org/10.1144/GSL.SP.1999.156.01.03

Shuster, D. L., Flowers, R. M., \& Farley, K. A. (2006). The influence of natural radiation damage on helium diffusion kinetics in apatite. Earth and Planetary Science Letters, 249(3-4), 148-161. https://doi.org/10.1016/j.epsl.2006.07.028

Simpson, G. D. H. (2006). How and to what extent does the emergence of orogens above sea level influence their tectonic development? Terra Nova, 18(6), 447-451. https://doi.org/10.1111/j.1365-3121.2006.00711.x

Sinclair, H. D. (2011). Thrust wedge/foreland basin systems. In C. Busby \& A. Azor (Eds.), Tectonics of Sedimentary Basins: Recent Advances (pp. 522-537). Chichester, UK: John Wiley \& Sons.

Sinclair, H. D., Gibson, M., Naylor, M., \& Morris, R. G. (2005). Asymmetric growth of the Pyrenees revealed through measurement and modeling of orogenic fluxes. American Journal of Science, 305(5), 369-406. https://doi.org/10.2475/ajs.305.5.369

Sinclair, H. D., \& Naylor, M. (2012). Foreland basin subsidence driven by topographic growth versus plate subduction. Geological Society of America Bulletin, 124(3-4), 368-379. https://doi.org/10.1130/B30383.1

Souquet, P., Peybernès, B., Bilotte, M., \& Debroas, E.-J. (1977). La chaîne alpine des Pyrénées. Géologie Alp, 53, $193-216$.

Spear, F. (1993). Metamorphic phase equilibria and pressure-temperature-time paths (pp. 352-356). Mineralogical Society of America. 
Stockli, D. F. (2005). Application of low-temperature thermochronometry to extensional tectonic settings. Reviews in Mineralogy and Geochemistry, 58(1), 411-448. https://doi.org/10.2138/rmg.2005.58.16

Stockli, D. F., Farley, K. A., \& Dumitru, T. A. (2000). Calibration of the apatite (U-Th)/He thermochronometer on an exhumed fault block, White Mountains, California. Geology, 28(11), 983-986. https://doi.org/10.1130/0091-7613(2000)28<983:COTAHT>2.0.CO;2

Sutra, E., Manatschal, G., Mohn, G., \& Unternehr, P. (2013). Quantification and restoration of extensional deformation along the Western Iberia and Newfoundland rifted margins: Strain distribution along rifted margins. Geochemistry, Geophysics, Geosystems, 14, 2575-2597. https://doi.org/10.1002/ggge.20135

Tagami, T., Farley, K. A., \& Stockli, D. F. (2003). (U-Th)/He geochronology of single zircon grains of known Tertiary eruption age. Earth and Planetary Science Letters, 207(1-4), 57-67. https://doi.org/10.1016/S0012-821X(02)01144-5

Teixell, A., Labaume, P., Ayarza, P., Espurt, N., de Saint Blanquat, M., \& Lagabrielle, Y. (2018). Crustal structure and evolution of the Pyrenean-Cantabrian belt: A review and new interpretations from recent concepts and data. Tectonophysics, 724-725, 146-170. https:// doi.org/10.1016/j.tecto.2018.01.009

Teixell, A., Labaume, P., \& Lagabrielle, Y. (2016). The crustal evolution of the west-central Pyrenees revisited: Inferences from a new kinematic scenario. Comptes Rendus Geoscience, 348(3-4), 257-267. https://doi.org/10.1016/j.crte.2015.10.010

Thomson, K. D., Stockli, D. F., Clark, J. D., Puigdefàbregas, C., \& Fildani, A. (2017). Detrital zircon (U-Th)/(He-Pb) double-dating constraints on provenance and foreland basin evolution of the Ainsa Basin, south-central Pyrenees, Spain. Tectonics, 36, 1352-1375. https:// doi.org/10.1002/2017TC004504

Tibari, B., Vacherat, A., Stab, M., Pik, R., Yeghicheyan, D., \& Hild, P. (2016). An alternative protocol for single zircon dissolution with application to (U-Th-Sm)/He thermochronometry. Geostandards and Geoanalytical Research https://doi.org/10.1111/j.1751908X.2016.00375.X, 40(3), 365-375.

Tournaire Guille, B. T., Olivier, P., Paquette, J.-L., Bosse, V., \& Guillaume, D. (2018). Evolution of the middle crust of the Pyrenees during the Paleozoic: New data on the plutonic rocks from the North Pyrenean Agly massif. International Journal of Earth Sciences. https://doi. org/10.1007/s00531-018-1652-4

Tugend, J., Manatschal, G., Kusznir, N. J., Masini, E., Mohn, G., \& Thinon, I. (2014). Formation and deformation of hyperextended rift systems: Insights from rift domain mapping in the Bay of Biscay-Pyrenees. Tectonics, 33, 1239-1276. https://doi.org/10.1002/ 2014TC003529

Vacherat, A., Mouthereau, F., Pik, R., Bellahsen, N., Gautheron, C., Bernet, M., et al. (2016). Rift-to-collision transition recorded by tectonothermal evolution of the northern Pyrenees: Cooling history of the northern Pyrenees. Tectonics, 35, 907-933. https://doi.org/ 10.1002/2015TC004016

Vacherat, A., Mouthereau, F., Pik, R., Bernet, M., Gautheron, C., Masini, E., et al. (2014). Thermal imprint of rift-related processes in orogens as recorded in the Pyrenees. Earth and Planetary Science Letters, 408, 296-306. https://doi.org/10.1016/j.epsl.2014.10.014

Vacherat, A., Mouthereau, F., Pik, R., Huyghe, D., Paquette, J.-L., Christophoul, F., et al. (2017). Rift-to-collision sediment routing in the Pyrenees: A synthesis from sedimentological, geochronological and kinematic constraints. Earth-Science Reviews, 172, 43-74. https:// doi.org/10.1016/j.earscirev.2017.07.004

Vauchez, A., Clerc, C., Bestani, L., Lagabrielle, Y., Chauvet, A., Lahfid, A., \& Mainprice, D. (2013). Preorogenic exhumation of the North Pyrenean Agly Massif (eastern Pyrenees-France). Tectonics, 32, 95-106. https://doi.org/10.1002/tect.20015

Vaudin, J.-L. (1982). Etude géologique de la couverture mésozoïque du massif de l'Agly (entre Estagel et Baixas, Pyrénées orientales). Thèse de doctorat. Toulouse: Université Paul Sabatier.

Vergés, J., Marzo, M., Santaeulària, T., Serra-Kiel, J., Burbank, D. W., Muñoz, J. A., \& Giménez-Montsant, J. (1998). Quantified vertical motions and tectonic evolution of the SE Pyrenean foreland basin. Geological Society, London, Special Publications, 134(1), 107-134. https://doi.org/10.1144/GSL.SP.1998.134.01.06

Vergés, J., Millán, H., Roca, E., Muñoz, J. A., Marzo, M., Cirés, J., et al. (1995). Eastern Pyrenees and related foreland basins: Pre-, synand post-collisional crustal-scale cross-sections. Marine and Petroleum Geology, 12(8), 903-915. https://doi.org/10.1016/02648172(95)98854-X

Vielzeuf, D. (1996). Les massifs nord-pyrénéens à soubassement granulitique. In BRGM-ITGE (Ed.), Synthèse Géologique et Géophysique Des Pyrénées. Introduction. Géophysique. Cycle Hercynien (Vol. 1, pp. 502-521). Orléans: BRGM.

Whitchurch, A. L., Carter, A., Sinclair, H. D., Duller, R. A., Whittaker, A. C., \& Allen, P. A. (2011). Sediment routing system evolution within a diachronously uplifting orogen: Insights from detrital zircon thermochronological analyses from the south-central Pyrenees. American Journal of Science, 311(5), 442-482. https://doi.org/10.2475/05.2011.03

Willett, S., Beaumont, C., \& Fullsack, P. (1993). Mechanical model for the tectonics of doubly vergent compressional orogens. Geology, 21(4), 371-374. https://doi.org/10.1130/0091-7613(1993)021<0371:MMFTTO>2.3.CO;2

Willett, S. D., \& Brandon, M. T. (2002). On steady states in mountain belts. Geology, 30(2), 175-178. https://doi.org/10.1130/00917613(2002)030<0175:OSSIMB > 2.0.CO;2

Wolfe, M. R., \& Stockli, D. F. (2010). Zircon (U-Th)/He thermochronometry in the KTB drill hole, Germany, and its implications for bulk He diffusion kinetics in zircon. Earth and Planetary Science Letters, 295(1-2), 69-82. https://doi.org/10.1016/j.epsl.2010.03.025

Yelland, A. J. (1991). Fission track thermotectonics of the Iberian-Eurasian plate collection. PhD thesis. Birkbeck College University of London, London. Retrieved from http://ethos.bl.uk/OrderDetails.do?uin=uk.bl.ethos.261137 